\title{
Is $\left[\mathbf{N}^{+}-\mathbf{H} \cdots \mathbf{O}\right]$ Hydrogen Bonding the Most Important Noncovalent Interaction in Macrocycle-Dibenzylammonium Ion Complexes?
}

\author{
Pin-Nan Cheng, ${ }^{\dagger}$ Po-Yi Huang,,$^{\dagger}$ Wan-Sheung Li,${ }^{\ddagger}$ Shau-Hua Ueng, ${ }^{\dagger}$ Wei-Chung Hung, ${ }^{\dagger}$ \\ Yi-Hung Liu, ${ }^{\dagger}$ Chien-Chen Lai, ${ }^{\S}$ Yu Wang, ${ }^{\dagger}$ Shie-Ming Peng, ${ }^{\dagger}$ Ito Chao, ${ }^{*},{ }^{\star}$ and \\ Sheng-Hsien Chiu*,† \\ Department of Chemistry, National Taiwan University, Taipei, Taiwan, R.O.C., \\ Institute of Chemistry, Academia Sinica, Nankang, Taipei, Taiwan, R.O.C., and \\ Department of Medical Genetics and Medical Research, China Medical University Hospital, \\ Taichung, Taiwan, R.O.C.
}

shchiu@ntu.edu.tw;ichao@chem.sinica.edu.tw

Received November 22, 2005
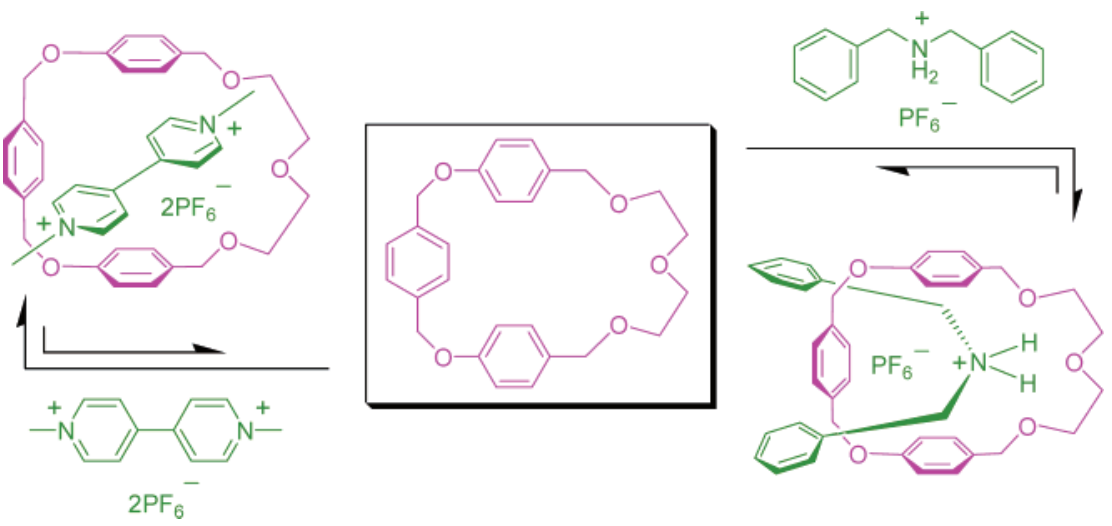

We report a new host molecule in which one diethylene glycol chain (i.e., a loop possessing only three oxygen atoms) incorporated along with two phenolic aromatic rings is linked by a xylene spacer into a macroring. The design of the molecular structure of this macrocycle "amplifies" any potential [cation $\cdots \pi]$, $\left[\mathrm{N}^{+}-\mathrm{H} \cdots \pi\right]$, and $\left[\mathrm{N}^{+} \mathrm{C}-\mathrm{H} \cdots \pi\right]$ interactions between the dibenzylammonium $\left(\mathrm{DBA}^{+}\right)$ion and the phenolic rings of the macrocycle; as such, these species display a very strong binding affinity in $\mathrm{CD}_{3} \mathrm{NO}_{2}\left(K_{\mathrm{a}}=\right.$ $15000 \mathrm{M}^{-1}$ ). The macroring also coordinates to bipyridinium ions in a [2]pseudorotaxane fashion, which makes it the smallest macrocycle (i.e., a 25-membered ring) known to complex both $\mathrm{DBA}^{+}$and bipyridinium ions in solution. To confirm unambiguously that these pseudorotaxanes exist in solution, we synthesized their corresponding interlocked molecules, namely rotaxanes and catenanes.

\section{Introduction}

After their serendipitous discovery by Pedersen, ${ }^{1}$ crown ethers have been applied extensively as phase-transfer agents, ${ }^{2}$ molecular sensors, ${ }^{3}$ and chiral separators ${ }^{4}$ because of their ability to form complexes with metal and quarternary ammonium ions. ${ }^{5}$

* Address correspondence to this author.

$\dagger$ National Taiwan University.

* Academia Sinica.

$\S$ China Medical University Hospital.

(1) Pedersen, C. J. Angew. Chem., Int. Ed. Engl. 1988, 27, 1021-1027.

(2) Polymer Science and Technology; Crown Ethers and Phase Transfer Catalysis in Polymer Science, Vol. 24; Mathias, L. J., Carraher, C. E., Jr., Eds.; Plenum Press: New York, 1984.
The more-recent finding ${ }^{6}$ that crown ethers form pseudorotaxane-like ${ }^{7}$ complexes with dialkylammonium ions in solution has been a boon to research efforts aimed at the development of functional interlocked molecular machinery. ${ }^{8}$ Many diverse interlocked molecular structures, such as molecular shuttles, ${ }^{9}$ molecular switches, ${ }^{10}$ and molecular elevators, ${ }^{11}$ have been

(3) (a) Takagi, M.; Nakano, K.; Nakashima, N. Pure Appl. Chem. 1989, 61, 1605-1612. (b) Gokel, G. W.; Leevy, W. M.; Weber, M. E. Chem. Rev. 2004, 104, 2723-2750.

(4) (a) Cram, D. J.; Helgeson, R. C.; Sousa, L. R.; Timko, J. M.; Newcomb, M.; Moreau, P.; De Jong, F.; Gokel, G. W.; Hoffman, D. H.; Domeier, L. A.; Peacock, S. C.; Madan, K.; Kaplan, L. Pure Appl. Chem. 1975, 43, 327-349. (b) Voegtle, F.; Knops, P. Angew. Chem., Int. Ed. Engl. 1991, 30, 958-960. 

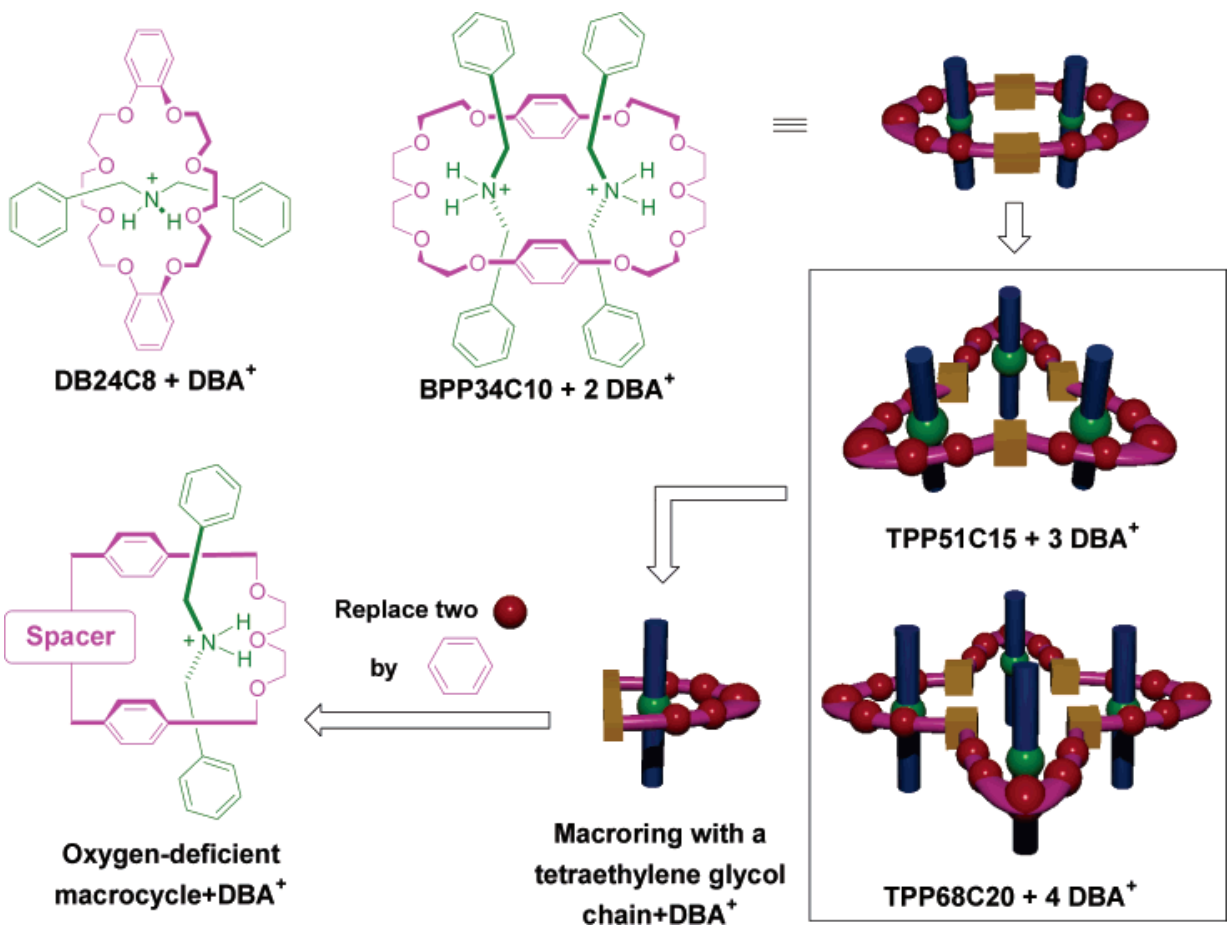

FIGURE 1. Cartoon and structural representations of the concept of deriving the oxygen-deficient macrocycle.

developed on the basis of such crown ether/dibenzylammonium $\left(\mathrm{DBA}^{+}\right)$ion $^{12}$ complexation. In this supramolecular system, $\left[\mathrm{N}^{+}-\mathrm{H} \cdots \mathrm{O}\right]$ and $\left[\mathrm{N}^{+} \mathrm{C}-\mathrm{H} \cdots \mathrm{O}\right]$ hydrogen bonding between the

(5) (a) Gokel, G. W. Crown Ethers and Cryptands; The Royal Society of Chemistry: Cambridge, UK, 1991. (b) Crown Ethers and Analogous Compounds; Hiraoka, M., Ed.; Elsevier: Amsterdam, The Netherlands, 1992.

(6) (a) Ashton, P. R.; Campbell, P. J.; Chrystal, E. J. T.; Glink, P. T.; Menzer, S.; Philp, D.; Spencer, N.; Stoddart, J. F.; Tasker, P. A.; Williams, D. J. Angew. Chem., Int. Ed. Engl. 1995, 34, 1865-1869. (b) Kolchinski, A. G.; Busch, D. H.; Alcock, N. W. J. Chem. Soc., Chem. Commun. 1995, $1289-1291$.

(7) (a) Asakawa, M.; Ashton, P. R.; Balzani, V.; Boyd, S. E.; Credi, A.; Mattersteig, G.; Menzer, S.; Montalti, M.; Raymo, F. M.; Ruffilli, C.; Stoddart, J. F.; Venturi, M.; Williams, D. J. Eur. J. Org. Chem. 1999, 985994. (b) Huang, F.; Gibson, H. W. Chem. Commun. 2005, 13, 1696-1698. (c) Sambrook, M. R.; Beer, P. D.; Wisner, J. A.; Paul, R. L.; Cowley, A. R.; Szemes, F.; Drew, M. G. B. J. Am. Chem. Soc. 2005, 127, 2292-2302. (d) Blight, B. A.; Van Noortwyk, K. A.; Wisner, J. A.; Jennings, M. C. Angew. Chem., Int. Ed. 2005, 44, 1499-1504. (e) Pascu, S. I.; Jarrosson, T.; Naumann, C.; Otto, S.; Kaiser, G.; Sanders, J. K. M. New J. Chem. 2005, 29, 80-89.

(8) (a) Kelly, T. R.; De Silva, H.; Silva, R. A. Nature 1999, 401, 150152. (b) Balzani, V.; Credi, A.; Raymo, F. M.; Stoddart, J. F. Angew. Chem., Int. Ed. 2000, 39, 3348-3391. (c) Collin, J.-P.; Dietrich-Buchecker, C.; Gaviña, P.; Jiménez-Molero, M. C.; Sauvage, J.-P. Acc. Chem. Res. 2001 34, 477-487. (d) Leigh, D. A.; Wong, J. K. Y.; Dehez, F.; Zerbetto, F. Nature 2003, 424, 174-179. (e) Jeon, W. S.; Kim, E.; Ko, Y. H.; Hwang, I.; Lee, J. W.; Kim, S.-Y.; Kim, H.-J.; Kim, K. Angew. Chem., Int. Ed. 2005, 44, 87-91.

(9) (a) Cao, J.; Fyfe, M. C. T.; Stoddart, J. F. J. Org. Chem. 2000, 65, 1937-1946. (b) Loeb, S. J.; Wisner, J. A. Chem. Commun. 2000, 19391940. (c) Mahoney, J. M.; Shukla, R.; Marshall, R. A.; Beatty, A. M.; Zajicek, J.; Smith, B. D. J. Org. Chem. 2002, 67, 1436-1440. (d) Wang, Q.-C.; Qu, D.-H.; Ren, J.; Chen, K.; Tian, H. Angew. Chem., Int. Ed. 2004, 43, 2661-2665. (e) Korybut-Daszkeiwicz, B.; Wieckowska, A.; Ilewicz, R.; Domagala, S.; Wozniak, K. Angew. Chem., Int. Ed. 2004, 43, 16681672.

(10) (a) Molecular Switches; Feringa, B. L., Ed.; VCH-Wiley: Weinheim, Germany, 2001. (b) Gatti, F. G.; León, S.; Wong, J. K. Y.; Bottari, G.; Allieri, A.; Morales, M. A. F.; Teat, S. J.; Frochet, C.; Leigh, D. A.; Brouwer, A. M.; Zerbetto, F. Proc. Natl. Acad. Sci. U.S.A. 2003, 100, 1014. (c) Tomasulo M.; Sortino S.; Raymo F. M. Org. Lett. 2005, 7, 11091112 . host and guest units has always been considered to be the most important stabilizing noncovalent interaction. ${ }^{6,13}$ For example, the solid-state structure of the [2]pseudorotaxane formed between the $\mathrm{DBA}^{+}$ion and dibenzo[24]crown-8 (DB24C8) displays both of these types of interactions. ${ }^{6 a}$ Indeed, it appears that aliphatic ether oxygen atoms are better hydrogen bond acceptors than are aromatic ether oxygen atoms. For example, consider the decrease in association constants that occurs upon the incorporation of additional benzo units into 24C8 macrocycles: the strength of binding to the $\mathrm{DBA}^{+}$ion follows the order [24]crown- $8>$ benzo[24]crown- $8>$ dibenzo[24]crown$8>$ tribenzo[24]crown- $8>$ tetrabenzo[24]crown-8. ${ }^{14}$ Macrocyclic effects ${ }^{15}$ play a role in these systems, too; bis- $m$ phenylene[26]crown-8 is a weaker binder than its isomer DB24C8 because its ring of eight oxygen atoms is not as well preorganized for effective hydrogen bonding to the $\mathrm{CH}_{2}$ $\mathrm{NH}_{2}{ }^{+} \mathrm{CH}_{2}$ unit of the $\mathrm{DBA}^{+}$ion. ${ }^{13,16}$ That is not to say that larger-ring crown ethers are necessarily always poorer binders. Bis- $p$-phenylene[34]crown-10 (BPP34C10), for instance, is capable of binding two $\mathrm{DBA}^{+}$ions simultaneously in solution in a 1:2 (host:guest) complex; ${ }^{17}$ in this case, the benefits of a five-oxygen-atom oligoether loop (featuring three "good" aliphatic ether oxygen atoms) outweigh the macrocycle's inability to completely encircle the $\mathrm{CH}_{2} \mathrm{NH}_{2}{ }^{+} \mathrm{CH}_{2}$ center of each ion. Indeed, the even-larger crown ethers tris- $p$-phenylene[51]crown-15 and tetrakis- $p$-phenylene[68]crown-20 also form complexes with $\mathrm{DBA}^{+}$ions (three and four of them, respectively), which suggests that single tetraethylene glycol loops are all that is really required for generating pseudorotaxanelike complexes in solution and in the solid state. ${ }^{18}$ This concept suggests that a more diverse set of macrocycles-not just those that technically could be called "crown ethers"- should also bind to $\mathrm{DBA}^{+}$ions (Figure 1). Naively, we might consider that as long as we place a suitable number of ether oxygen atoms (say, five of them) into a macrocycle then its remaining structure 


\section{SCHEME 1}

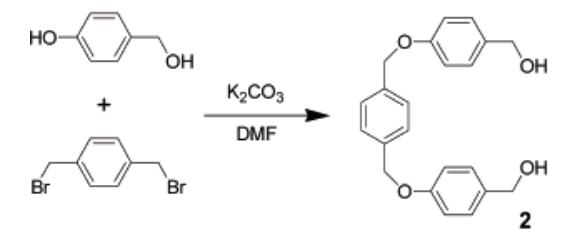

would be replaceable-as long as there is enough room, of course, for the threading of the guest ion (i.e., at least 24 ring atoms,${ }^{19}$ or thereabout). In this paper, we demonstrate, however, that this logic is not entirely correct. We have found that a macrocycle containing merely a diethylene glycol loop (i.e., one with just three ether oxygen atoms) is an unusually strong binder toward $\mathrm{DBA}^{+}$ions. ${ }^{20}$ In fact, it binds more strongly to the $\mathrm{DBA}^{+}$ ion than does the corresponding macrocycle containing an extra ethylene glycol unit (i.e., a triethylene glycol loop). This enigmatic behavior suggests that there may be other noncovalent interactions that stabilize these complexes. We suggest that, in some cases, the $[\text { cation } \cdots \pi]^{21}$ interaction-along with other relatively weak noncovalent interactions, such as $\left[\mathrm{N}^{+}-\mathrm{H} \cdots \pi\right]^{22}$ and $\left[\mathrm{N}^{+} \mathrm{C}-\mathrm{H} \cdots \pi\right]^{22 \mathrm{c}, \mathrm{d}, 23}$ bonding - that exists between the $\mathrm{DBA}^{+}$

(11) Badjic, J. D.; Balzani, V.; Credi, A.; Silvi, S.; Stoddart, J. F. Science 2004, 303, 1845-1849.

(12) (a) Cantrill, S. J.; Pease, A. R.; Stoddart, J. F. J. Chem. Soc., Dalton Trans. 2000, 3715-3734. (b) Clifford, T.; Abushamleh, A.; Busch, D. H. Proc. Natl. Acad. Sci. U.S.A. 2002, 99, 4830-4836. (c) Gibson, H. W. Yamaguchi, N.; Jones, J. W. J. Am. Chem. Soc. 2003, 125, 3522-3533.

(13) For example, it has been stated that "the hydrogen bonding is the much stronger, primary stabilizing variable in these systems"; see: Bryant, W. S.; Guzei, I. A.; Rheingold, A. L.; Merola, J. S.; Gibson, H. W. J. Org. Chem, 1998, 63, 7634-7639.

(14) Ashton, P. R.; Bartsch, R. A.; Cantrill, S. J.; Hanes, R. E., Jr.; Hickingbottom, S. K.; Lowe, J. N.; Preece, J. A.; Stoddart, J. F.; Talanov, V. S.; Wang, Z.-H. Tetrahedron Lett. 1999, 40, 3661-3664.

(15) (a) Sun, Y.; Kollman, P. A. J. Am. Chem. Soc. 1995, 117, 3599604. (b) Haack, K.-J.; Goddard, R.; Poerschke, K.-R. J. Am. Chem. Soc. 1997, 119, 7992-7999.

(16) Cantrill, S. J.; Fulton, D. A.; Heiss, A. M.; Pease, A. R.; Stoddart, J. F.; White, A. J. P.; Williams, D. J. Chem. Eur. J. 2000, 6, 2274-2287.

(17) Ashton, P. R.; Chrystal, E. J. T.; Glink, P. T.; Menzer, S.; Schiavo, C.; Stoddart, J. F.; Tasker, P. A.; Williams, D. J. Angew. Chem., Int. Ed. Engl. 1995, 34, 1869-1871.

(18) Ashton, P. R.; Fyfe, M. C. T.; Glink, P. T.; Menzer, S.; Stoddart, J. F.; White, A. J. P.; Williams, D. J. J. Am. Chem. Soc. 1997, 119, 1251412524.

(19) (a) Gibson, H. W.; Ganguly, S. Macromolecules 1993, 26, 24082412. (b) Glink, P. T.; Schiavo, C.; Stoddart, J. F.; Williams, D. J. Chem. Commun. 1996, 1483-1490.

(20) Cheng, P.-N.; Hung, W.-C.; Chiu, S.-H. Tetrahedron Lett. 2005 , $46,4239-4242$

(21) (a) Ma, J. C.; Dougherty, D. A. Chem. Rev. 1997, 97, 1303-1324. (b) Cametti, M.; Nissinen, M.; Dalla Cort, A.; Mandolini, L.; Rissanen, K. J. Am. Chem. Soc. 2005, 127, 3831-3837. The stablization energies of cation $-\pi$ interactions range from -0.71 to $-2.63 \mathrm{kcal} / \mathrm{mol}$; see: (c) Schneider, H. J.; Blatter, T.; Zimmerman, P. Angew. Chem., Int. Ed. Engl. 1990, 29, 1161-1162. (d) Kearney, P. C.; Mizoue, L. S.; Kumpf, R. A.; Forman, J. E.; McCurdy, A.; Dougherty, D. A. J. Am. Chem. Soc. 1993 , 115, 9907-9919. (e) Hunter, C. A.; Low, C. M. R.; Rotger, C.; Vinter, J. G.; Zonta, C. Proc. Natl. Acad. Sci. U.S.A. 2002, 99, 4873-4876.

(22) (a) Palit, S. R.; Mukherjee, S.; De, S. K. J. Phys. Chem. 1971, 75 , 2404-2405. (b) Nikolic, A. D.; Kobilarov, N. L.; Brzic, A. N. J. Mol. Struct. 1983, 99, 179-188. The interaction energies of benzene-methane $(\mathrm{C}-$ $\mathrm{H} \cdots \pi)$ and benzene-ammonia $(\mathrm{N}-\mathrm{H} \cdots \pi)$ complexes have been calculated to be -1.45 and $-2.22 \mathrm{kcal} / \mathrm{mol}$, respectively; i.e., ca. $30-40 \%$ of the hydrogen bonding energy of the water dimer. See: (c) Tsuzuki, S.; Honda, K.; Uchimaru, T.; Mikami, M.; Tanabe, K. J. Am. Chem. Soc. 2000, 122, 11450-11458. (d) Tsuzuki, S.; Honda, K.; Uchimaru, T.; Mikami, M.; Tanabe, K. J. Am. Chem. Soc. 2000, 122, 3746-3753.

(23) (a) Nishio, M.; Umezawa, Y.; Hirota, M.; Takeuchi, Y. Tetrahedron 1995, 51, 8665-8701. (b) Iwamoto, H.; Takahashi, N.; Maeda, T.; Hidaka, Y.; Fukazawa, Y. Tetrahedron Lett. 2005, 46, 6839-6842.

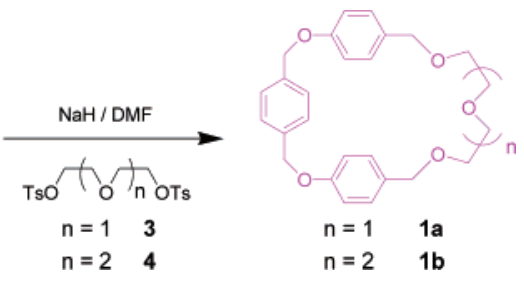

ion and $\pi$-electron-rich aromatic rings of the macrocycle can be as stabilizing as the more-traditional $\left[\mathrm{N}^{+}-\mathrm{H} \cdots \mathrm{O}\right]^{24}$ and $\left[\mathrm{N}^{+} \mathrm{C}-\mathrm{H} \cdots \mathrm{O}\right]^{25}$ hydrogen bonds.

$[$ Cation $\cdots \pi]$ interactions are very important interactions that exist between quarternary ammonium ions and aromatic host macrocycles such as calix[4] $\operatorname{arenes}^{26}$ and cyclophanes. ${ }^{27} \mathrm{Al}-$ though $\left[\mathrm{N}^{+}-\mathrm{H} \cdots \pi\right]$ and $\left[\mathrm{N}^{+} \mathrm{C}-\mathrm{H} \cdots \pi\right]$ interactions have not yet been considered as important primary interactions in hostguest systems in solution, they are recognized to play an important role in molecular packing in the solid state. ${ }^{28}$ Because we believed that $\mathrm{DBA}^{+}$ions should interact favorably with $\pi$-electron-rich aromatic rings through $\left[\mathrm{N}^{+}-\mathrm{H} \cdots \pi\right],\left[\mathrm{N}^{+} \mathrm{C}-\right.$ $\mathrm{H} \cdots \pi$ ], and [cation $\cdots \pi$ ] interactions, it seemed reasonable to consider replacing the two terminal ethylene glycol units in a tetraethylene glycol strand with two $\pi$-electron-rich benzyl units such that the $[$ cation $\cdots \pi]$ interaction and potential $\left[\mathrm{N}^{+}-\mathrm{H} \cdots \pi\right]$ and $\left[\mathrm{N}^{+} \mathrm{C}-\mathrm{H} \cdots \pi\right]$ interactions that may form between the aromatic rings and the $\mathrm{CH}_{2} \mathrm{NH}_{2}{ }^{+} \mathrm{CH}_{2}$ unit of the $\mathrm{DBA}^{+}$ion will compensate for the loss of any $\left[\mathrm{N}^{+}-\mathrm{H} \cdots \mathrm{O}\right]$ and $\left[\mathrm{N}^{+} \mathrm{C}-\mathrm{H} \cdots \mathrm{O}\right]$ hydrogen bonds. To enhance any macrocyclic effect, we closed the loop of this macrocycle by linking the two phenol units through a $p$-xylyl spacer. This macrocycle displays a very strong binding affinity toward the $\mathrm{DBA}^{+}$ion in $\mathrm{CD}_{3} \mathrm{NO}_{2}\left(K_{\mathrm{a}}=15000\right.$ $\mathrm{M}^{-1}$ ) and, remarkably, it binds much more tightly to these ions than do its corresponding symmetrical crown ether (bis- $p$-xylyl[26]crown-6) and an analogous macrocycle containing a triethylene glycol loop. Relative to normal crown ethers, these macrocycles belong to a new class of "oxygen-deficient" hosts for $\mathrm{DBA}^{+}$ions; they feature aromatic rings as crucial structural elements and not just as linkers or synthetically amenable components. Moreover, we have found that these hosts also recognize bipyridinium ions; indeed, they are the smallest macrocycles known to date that form pseudorotaxane-like complexes with both $\mathrm{DBA}^{+}$and bipyridinium ions in solution. To confirm unambiguously the existence of these pseudorotaxane-like complexes in solution, we have synthesized and characterized a number of interlocked molecules - rotaxanes and catenanes-incorporating the new macrocycles.

\section{Result and Discussion}

Design, Syntheses, and Complexation of the New Macrocycles. Macrocycles 1a and 1b (Scheme 1) were both synthesized with use of a simple two-step approach. The reaction

(24) The strength of a hydrogen bonding interaction depends on the characteristics of the donor and acceptor as well as their environment, but generally it ranges between 1 and $5 \mathrm{kcal} / \mathrm{mol}$. For detailed descriptions of hydrogen bonding interaction, see: (a) Jeffrey, G. A. An Introduction to Hydrogen Bonding; Oxford University Press: New York, 1997. (b) Desiraju, G. R.; Steiner, T. The Weak Hydrogen Bond in Structural Chemistry and Biology; Oxford University Press: New York, 1999.

(25) According to calculations, the $\mathrm{C}-\mathrm{H} \cdots \mathrm{O}$ interactions between $\mathrm{CH}_{4}$ and $\mathrm{H}_{2} \mathrm{O}$ vary in strength between 0.3 and $0.7 \mathrm{kcal} / \mathrm{mol}$. Replacing each $\mathrm{H}$ atom of $\mathrm{CH}_{4}$ with an $\mathrm{F}$ atom adds ca. $1 \mathrm{kcal} / \mathrm{mol}$ to the binding energy. See: (a) Novoa, J. J.; Mota, F. Chem. Phys. Lett. 1997, 266, 23-30. (b) Gu, Y.; Kar, T.; Scheiner, S. J. Am. Chem. Soc. 1999, 121, 9411-9422. 
(a)

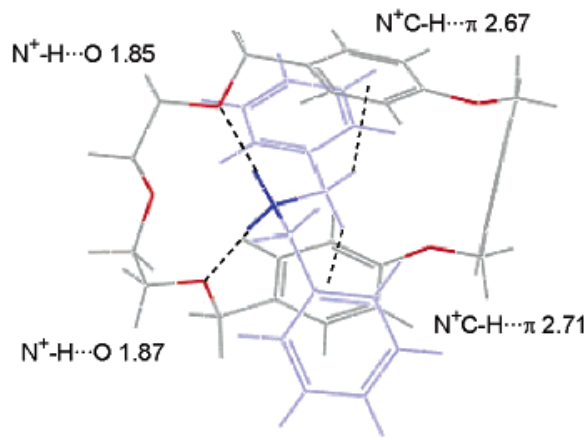

(b)

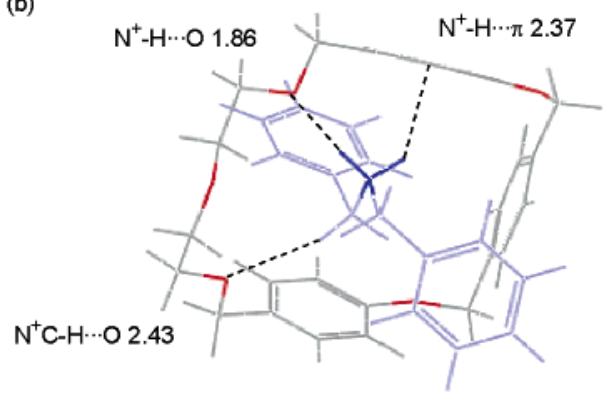

FIGURE 2. (a) Lowest energy structure obtained after optimization of sampled structures obtained from 5000-ps MD of 1a $\supset \mathrm{DBA}^{+}$in a water continuum model. (b) A structure $1.22 \mathrm{kcal} / \mathrm{mol}$ above the lowest energy structure displays a different set of binding interactions. All of the $\mathrm{H} \cdots \pi$ contacts are measured relative to the centroid of the relevant phenyl ring; the $\mathrm{DBA}^{+}$ion is light blue; its ${ }^{+} \mathrm{NH}_{2}$ unit is dark blue.

between 4-hydroxybenzyl alcohol and $\alpha, \alpha^{\prime}$-dibromo- $p$-xylene under basic conditions afforded the diol $\mathbf{2}$ in $90 \%$ yield and the following [1+1] macrocyclization reactions between diol 2 and the diethylene and triethylene glycol ditosylates ( $\mathbf{3}$ and $\mathbf{4}$ ) gave the desired macrocycles $\mathbf{1 a}$ and $\mathbf{1 b}$, respectively. ${ }^{29}$ The lowest energy structure of $\mathbf{1 a} \supset \mathrm{DBA}^{+}$located in the gas phase (see the computational details below) is similar to one found in water (Figure 2a); this finding suggests that macrocycle 1a presents the oxygen atoms of its diethylene glycol chain and the two $\pi$-electron-rich phenolic rings in an appropriate position to provide a good receptor site for $\left[\mathrm{N}^{+}-\mathrm{H} \cdots \mathrm{O}\right]$ and $\left[\mathrm{N}^{+} \mathrm{C}-\mathrm{H} \cdots\right.$ $\pi$ ] interactions with the $\mathrm{CH}_{2} \mathrm{NH}_{2}{ }^{+} \mathrm{CH}_{2}$ center of a threaded $\mathrm{DBA}^{+}$ion. Because one local minimum of the same complex, one that displays an $\left[\mathrm{N}^{+}-\mathrm{H} \cdots \pi\right]$ interaction between the two components, is located only $1.22 \mathrm{kcal} / \mathrm{mol}$ above the lowest energy structure (Figure 2b), it appears that such interactions may also play a role in stabilizing this supramolecular complex.

To test this hypothesis, we examined the ${ }^{1} \mathrm{H}$ NMR spectrum (Figure $3 b)$ of an equimolar mixture $(10 \mathrm{mM})$ of macrocycle 1a and $\mathrm{DBA} \cdot \mathrm{PF}_{6}$ in $\mathrm{CDCl}_{3} / \mathrm{CD}_{3} \mathrm{CN}(1: 1)$. We observe three sets of resonances, which represent the free macroring $\mathbf{1 a}$ (cf. Figure 3a), free DBA $\cdot \mathrm{PF}_{6}$ (cf. Figure 3c), and the 1:1 complex formed between 1a and the $\mathrm{DBA}^{+}$ion. This phenomenon implies that the rates of complexation and decomplexation are both slow on the ${ }^{1} \mathrm{H}$ NMR time scale at $400 \mathrm{MHz}$ and $298 \mathrm{~K}$. The splitting of the originally overlapping signals for the protons of the diethylene glycol unit's two methylene groups in macrocycle 1a into two separate multiplets-one shifted upfield to $\delta 3.06$ and the other downfield to $\delta 3.59$-in the presence of the salt suggests that hydrogen bonding probably takes place between the host and guest, but the most remarkable shift occurs for the methylene protons adjacent to the ammonium center. When uncomplexed, these protons resonate at ca. $4.17 \mathrm{ppm}$, but this

(26) (a) Lhotak, P.; Shinkai, S. J. Phys. Org. Chem. 1997, 10, 273285. (b) Macias, A. T.; Norton, J. E.; Evanseck, J. D. J. Am. Chem. Soc. 2003, 125, 2351-2360.

(27) (a) Bartoli, S.; Roelens, S. J. Am. Chem. Soc. 2002, 124, 83078315. (b) Sarri P.; Venturi F.; Cuda F.; Roelens, S. J. Org. Chem. 2004 $69,3654-3661$

(28) (a) Reddy, C. M.; Nangia, A.; Lam, C.-K.; Mak, T. C. W CrystEngComm 2002, 4, 323-325. (b) Reddy, C. M.; Reddy, L. S.; Aitipamula, S.; Nangia, A.; Lam, C.-K.; Mak, T. C. W. CrystEngComm 2005, 7, 44-52. (c) Glidewell, C.; Low, J. N.; Skakle, J. M. S.; Wardell, J. L. Acta Crystallogr. Sect. C: Cryst. Struct. Commun. 2005, 61, o185o187. (d) Cetina, M.; Nagl, A.; Prekupec, S.; Raic-Malic, S.; Mintas, M. Acta Crystallogr. Sect. C: Cryst. Struct. Commun. 2005, 61, o158-o160.

(29) The yield of the reaction is ca. 5\%; adding 10 equiv of $\mathrm{LiClO}_{4}$, $\mathrm{KPF}_{6}$, or $\mathrm{Cs}_{2} \mathrm{CO}_{3}$ to the reaction mixture did not increase the yield significantly, suggesting that the templating effects of these alkali metal ions are very weak in these macrocyclization reactions.

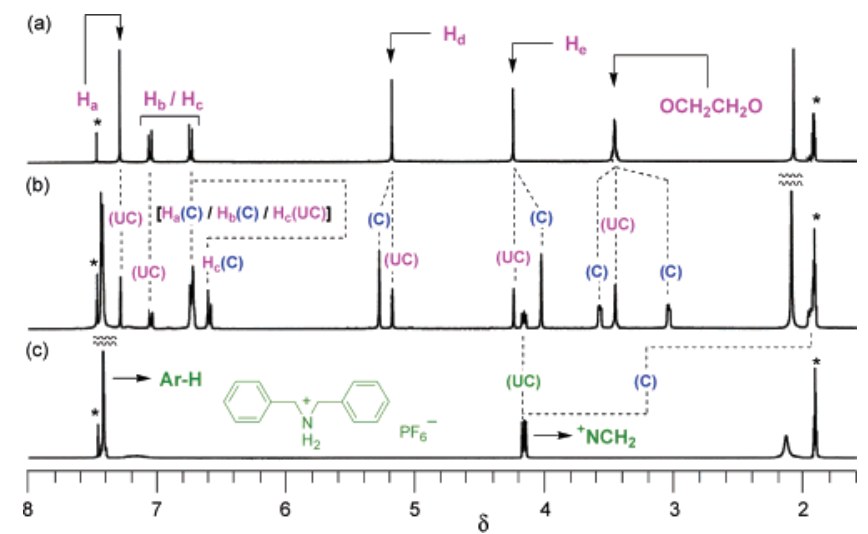

FIGURE 3. Partial ${ }^{1} \mathrm{H}$ NMR spectra $\left[400 \mathrm{MHz}, \mathrm{CDCl}_{3} / \mathrm{CD}_{3} \mathrm{CN}(1\right.$ : 1), $298 \mathrm{~K}$ ] of (a) macrocycle 1a, (b) an equimolar mixture of 1a and $\mathrm{DBA} \cdot \mathrm{PF}_{6}(10 \mathrm{mM})$, and (c) $\mathrm{DBA} \cdot \mathrm{PF}_{6}$. The descriptors (c) and (uc) refer to complexed and uncomplexed states of the components.

signal experiences an upfield shift of $>2$ ppm (to $\delta$ 1.95) upon complexation with $\mathbf{1 a}$, which suggests that the $\mathrm{NH}_{2}{ }^{+}$center is positioned in the shielding zone between the two phenol units of $1 \mathrm{a}$, as would be expected for the coexistence of $\left[\mathrm{N}^{+}-\mathrm{H} \cdots \mathrm{O}\right]$ hydrogen bonding with $\left[\mathrm{N}^{+} \mathrm{C}-\mathrm{H} \cdots \pi\right]$ interactions. Unfortunately, we were not able to detect, possibly because of severe broadening, the signal for the resonance of the $\mathrm{NH}_{2}{ }^{+}$protons, which we expect to also undergo a significant upfield shift. The resonances of the phenolic $\mathrm{CH}$ protons shifted upfield to 6.60 and $6.74 \mathrm{ppm}$ from their original positions $(\delta 6.74$ and 7.06, respectively), which suggests the existence of possible arylaryl interactions ${ }^{30}$ caused by the threading of the $\mathrm{DBA}^{+}$ion into the cavity of macroring 1a. Thus, these shifts suggest that the complex formed between macrocycle $\mathbf{1 a}$ and the $\mathrm{DBA}^{+}$ion in solution is likely to have the geometry of a [2]pseudorotaxane $\left[(\mathbf{1 a} \supset \mathrm{DBA}) \cdot \mathrm{PF}_{6}\right]$ (Scheme 2). Using a single-point method, ${ }^{31}$ we determined the association constants $\left(K_{\mathrm{a}}\right)$ of this system to be $550 \mathrm{M}^{-1}$ in $\mathrm{CDCl}_{3} / \mathrm{CD}_{3} \mathrm{CN}(1: 1)$ and $15000 \mathrm{M}^{-1}$ in $\mathrm{CD}_{3} \mathrm{NO}_{2}$; i.e., the binding strength is comparable to those of crown ethercontaining complexes. ${ }^{32}$ This result suggests that noncovalent interactions, such as [cation $\cdots \pi],\left[\mathrm{N}^{+}-\mathrm{H} \cdots \pi\right]$, and $\left[\mathrm{N}^{+} \mathrm{C}-\right.$ $\mathrm{H} \cdots \pi]$ interactions between the two phenolic rings and the $\mathrm{DBA}^{+}$ion, must contribute significantly toward stabilizing the pseudorotaxane complex because macrocycle 1a contains only three oxygen atoms that may behave as $\left[\mathrm{N}^{+}-\mathrm{H} \cdots \mathrm{O}\right]$ and $\left[\mathrm{N}^{+} \mathrm{C}-\mathrm{H} \cdots \mathrm{O}\right]$ hydrogen bond receptors.

To elucidate the effect that an extra oxygen atom in the oligoethylene glycol motif has on the binding of this category 

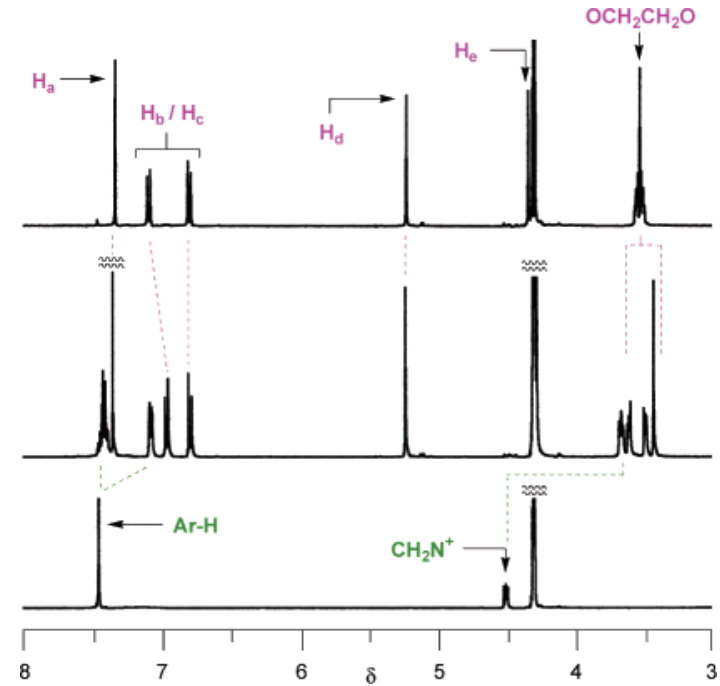

FIGURE 4. Partial ${ }^{1} \mathrm{H}$ NMR spectra (400 MHz, $\mathrm{CD}_{3} \mathrm{NO}_{2}$, $298 \mathrm{~K}$ ) of (a) macrocycle $\mathbf{1 b},(b)$ an equimolar mixture of $\mathbf{1 b}$ and $\mathrm{DBA} \cdot \mathrm{PF}_{6}(10$ $\mathrm{mM}$ ), and (c) $\mathrm{DBA} \cdot \mathrm{PF}_{6}$.

of macrocycles to $\mathrm{DBA}^{+}$ions, we examined the interaction between $\mathrm{DBA} \cdot \mathrm{PF}_{6}$ and macrocycle $\mathbf{1 b}$, which contains an extra $\mathrm{CH}_{2} \mathrm{CH}_{2} \mathrm{O}$ unit. The ${ }^{1} \mathrm{H}$ NMR spectrum of an equimolar mixture of $\mathbf{1 b}$ and $\mathrm{DBA} \cdot \mathrm{PF}_{6}$ in $\mathrm{CD}_{3} \mathrm{NO}_{2}(10 \mathrm{mM})$ at room temperature displays significant changes in the chemical shifts of the protons of the complex relative to those of its free components (Figure 4). Unlike the $1 \mathbf{a} / \mathrm{DBA}^{+}$ion system, whose rates of complexation and decomplexation are slow at $400 \mathrm{MHz}$ and $298 \mathrm{~K}$, the exchange rates for the complexation of $\mathbf{1 b}$ and the $\mathrm{DBA}^{+}$ion are fast under the same conditions so that we observe timeaveraged signals in this spectrum.

In the spectrum of the complex, the large upfield shift (from $\delta 4.50$ to 3.64) of the signal for the protons of the benzylic methylene groups adjacent to the $\mathrm{NH}_{2}{ }^{+}$center of the $\mathrm{DBA}^{+}$ ion suggests that the $\mathrm{NH}_{2}{ }^{+}$center is positioned within the cavity of the macrocycle and is stabilized possibly through $\left[\mathrm{N}^{+}-\right.$ $\mathrm{H} \cdots \mathrm{O}]$ and $\left[\mathrm{N}^{+} \mathrm{C}-\mathrm{H} \cdots \pi\right]$ interactions. This hypothesis is supported by the observation that, upon complexation, the formerly "tight" multiplet $(\delta 3.48-3.57)$ for the methylene protons of the $\mathrm{OCH}_{2} \mathrm{CH}_{2} \mathrm{O}$ units becomes dispersed over a wider range of chemical shifts $(\delta 3.39-3.61)$ and is resolved into three signals (Figure $4 \mathrm{~b}$ ). The shifts in the signals of the aromatic protons suggest the existence of interactions between the electronically complementary aromatic rings of macrocycle $\mathbf{1 b}$ and $\mathrm{DBA}^{+}$ion. A Job plot based on the ${ }^{1} \mathrm{H}$ NMR spectroscopic data obtained in $\mathrm{CD}_{3} \mathrm{NO}_{2}$ provided conclusive evidence for 1:1

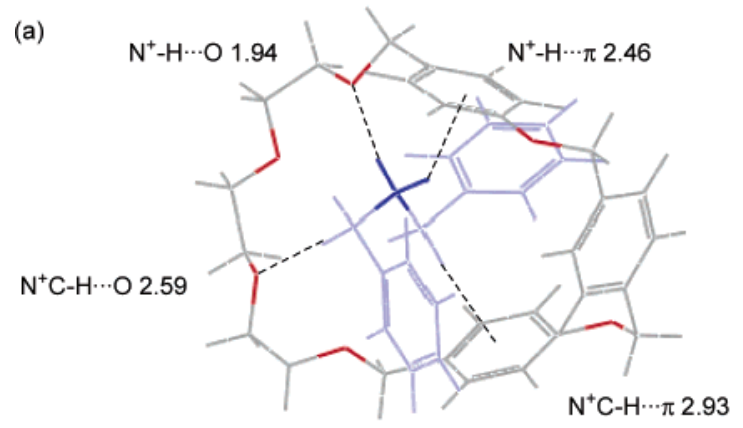

complexation (see the Supporting Information). According to

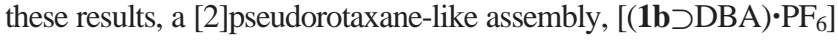
(Scheme 2), seems to be the likely structure of the complex formed between $\mathbf{1 b}$ and $\mathrm{DBA}^{+}$ions in $\mathrm{CD}_{3} \mathrm{NO}_{2}$. From a ${ }^{1} \mathrm{H}$ NMR spectroscopic dilution experiment, we determined the association constant $\left(K_{\mathrm{a}}\right)$ for this complex in $\mathrm{CD}_{3} \mathrm{NO}_{2}$ to be 2200 $\pm 40 \mathrm{M}^{-1}$, which is ca. 7-fold weaker than that for the complex formed between $1 \mathrm{a}$ and $\mathrm{DBA}^{+}$in the same solvent $\left(K_{\mathrm{a}}=15000\right.$ $\left.\mathrm{M}^{-1}\right)$. This result suggests that although macrocycle $\mathbf{1 b}$ contains an additional hydrogen bond receptor (i.e., four oxygen atoms, cf. three for 1a), which, intuitively, should enhance the favorability of $\left[\mathrm{N}^{+}-\mathrm{H} \cdots \mathrm{O}\right]$ and $\left[\mathrm{N}^{+} \mathrm{C}-\mathrm{H} \cdots \mathrm{O}\right]$ hydrogen bonding, its larger ring size leads to a structure that is less preorganized to accommodate a more-complete range of noncovalent interactions simultaneously (i.e., a diminished macrocyclic effect). The noncovalent interactions that exist in the lowest energy structure of the complex $\mathbf{1 b} \supset \mathrm{DBA}^{+}$in the gas phase are similar to the ones found in $\mathbf{1 a} \supset \mathrm{DBA}^{+}$(Figure 2a). The larger size of macrocycle $\mathbf{1 b}$, however, causes the distance between the proton and the aromatic ring in one of the $\left[\mathrm{N}^{+} \mathrm{C}-\right.$ $\mathrm{H} \cdots \pi]$ interactions to be elongated significantly. Interestingly, the lowest energy structure located for $\mathbf{1 b} \supset \mathrm{DBA}^{+}$in water features $\left[\mathrm{N}^{+}-\mathrm{H} \cdots \mathrm{O}\right],\left[\mathrm{N}^{+} \mathrm{C}-\mathrm{H} \cdots \mathrm{O}\right],\left[\mathrm{N}^{+}-\mathrm{H} \cdots \pi\right]$, and $\left[\mathrm{N}^{+} \mathrm{C}-\right.$ $\mathrm{H} \cdots \pi]$ interactions (Figure 5). Thus, in the complexation of the $\mathrm{DBA}^{+}$ion by crown ether-type hosts, our previous assumption that electron-rich aromatic rings can replace some oxygen atoms seems to be supported by both experimental and calculated results, i.e., the loss of $\left[\mathrm{N}^{+}-\mathrm{H} \cdots \mathrm{O}\right]$ and $\left[\mathrm{N}^{+} \mathrm{C}-\mathrm{H} \cdots \mathrm{O}\right]$ hydrogen bonds can be compensated for by $\left[\mathrm{N}^{+}-\mathrm{H} \cdots \pi\right]$ and $\left[\mathrm{N}^{+} \mathrm{C}-\right.$ $\mathrm{H} \cdots \pi]$ interactions between aromatic rings and the $\mathrm{CH}_{2} \mathrm{NH}_{2}{ }^{+} \mathrm{CH}_{2}$ unit of the $\mathrm{DBA}^{+}$ion.

To estimate the structural importance of the xylene spacer, we synthesized the corresponding symmetrical crown ether $\mathbf{5}$ from $\alpha, \alpha^{\prime}$-dibromo- $p$-xylene and diethylene glycol through a one-step [2+2] macrocyclizaton (Scheme 3). When we mixed equamolar amounts of macrocycle $\mathbf{5}$ and $\mathrm{DBA} \cdot \mathrm{PF}_{6}$ in $\mathrm{CD}_{3} \mathrm{NO}_{2}$ at room temperature, we observed a noticeable shifting of signals in the ${ }^{1} \mathrm{H}$ NMR spectrum relative to those of the free species (Figure 6); the rates of the complexation and decomplexation processes were fast on the NMR spectroscopic time scale under these conditions. The upfield shift of the benzylic methylene groups adjacent to the $\mathrm{NH}_{2}{ }^{+}$center of the $\mathrm{DBA}^{+}$ion and the dispersal of the methylene protons of the $\mathrm{OCH}_{2} \mathrm{CH}_{2} \mathrm{O}$ units into two multiplets over a range of chemical shifts $(\delta 3.62-3.72)$ suggest that the $\mathrm{NH}_{2}{ }^{+}$center is stabilized possibly through $\left[\mathrm{N}^{+}-\right.$ $\mathrm{H} \cdots \mathrm{O}]$ and $\left[\mathrm{N}^{+} \mathrm{C}-\mathrm{H} \cdots \pi\right]$ interactions. Again, a Job plot based on the ${ }^{1} \mathrm{H}$ NMR spectroscopic absorption in $\mathrm{CD}_{3} \mathrm{NO}_{2}$ afforded conclusive evidence for 1:1 complexation (see the Supporting

(b)

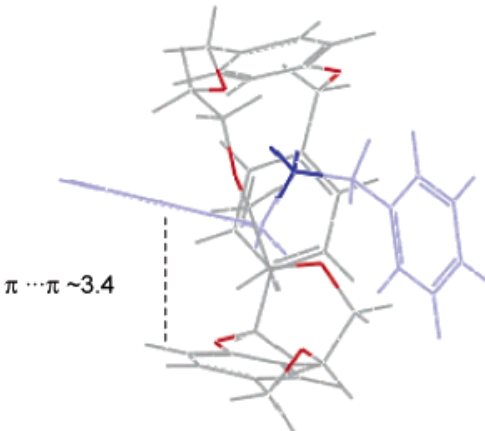

FIGURE 5. (a) Lowest energy structure obtained after optimization of sampled structures obtained from $5000-\mathrm{ps}$ MD of $\mathbf{1 b} \supset \mathrm{DBA}^{+}$in a water continuum model; (b) alternative view of the same structure. 


\section{SCHEME 2}

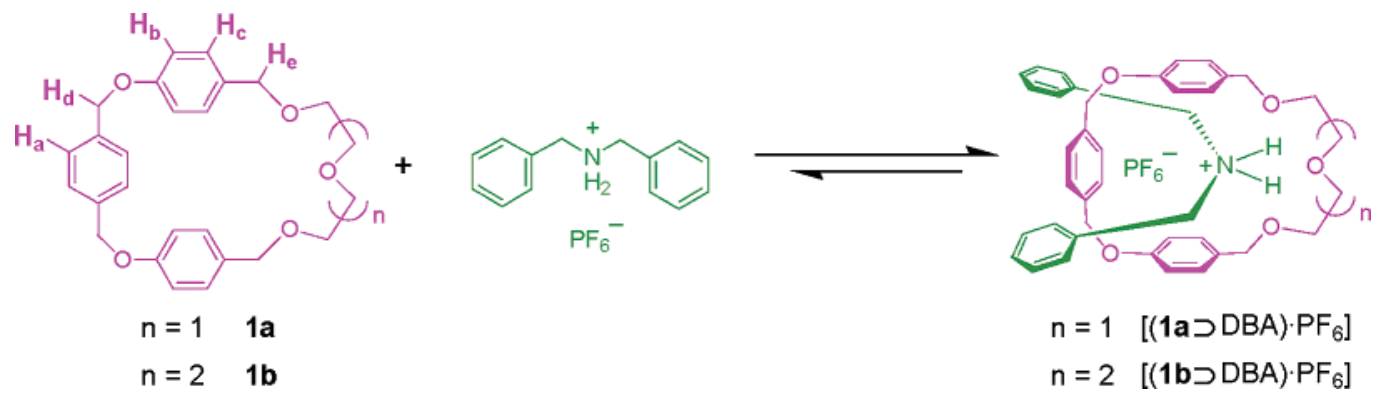

SCHEME 3

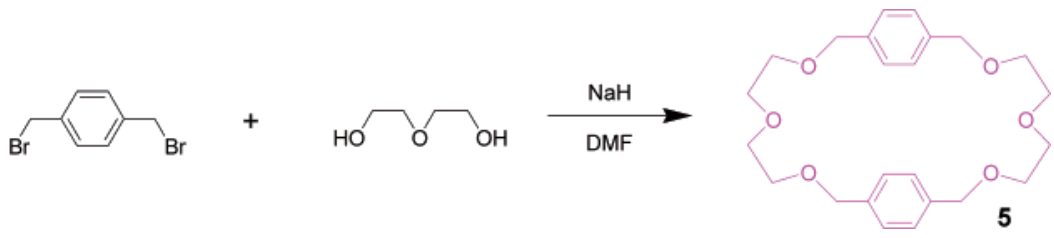

\section{SCHEME 4}

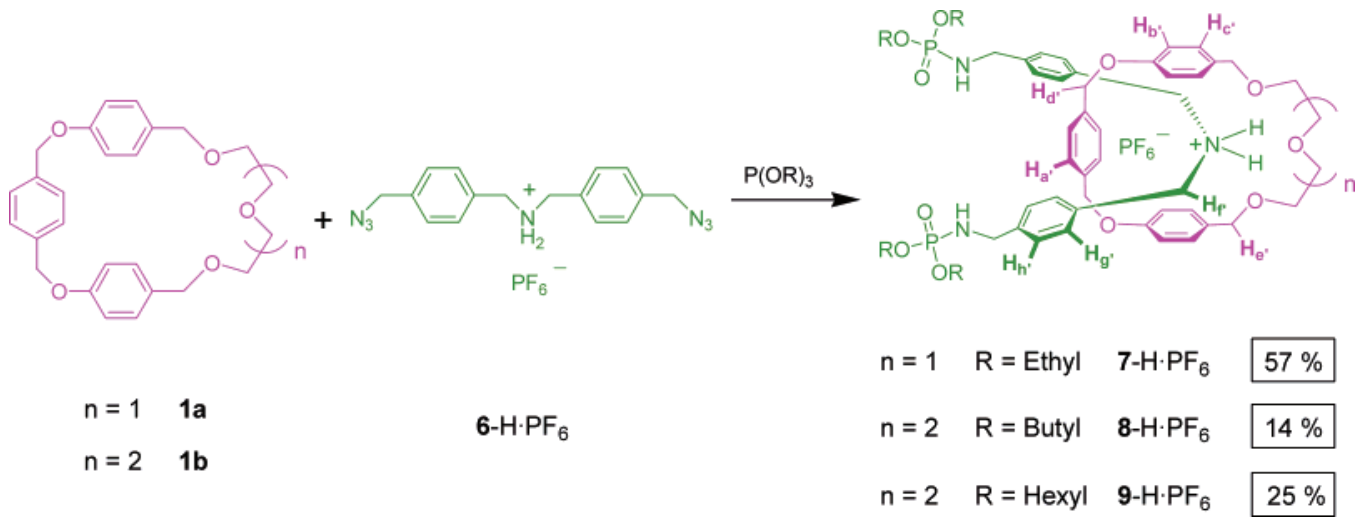

Information). We determined, through a ${ }^{1} \mathrm{H}$ NMR spectroscopic dilution experiment, the association constant for the interaction between macrocycle 5 and the $\mathrm{DBA}^{+}$ion in $\mathrm{CD}_{3} \mathrm{NO}_{2}$ to be 340 $\pm 40 \mathrm{M}^{-1}$, which is ca. 50 -fold weaker than the one between macrocycle 1a and the $\mathrm{DBA}^{+}$ion. This result suggests-again, counterintuitively - that the presence of a $p$-xylyl unit is more

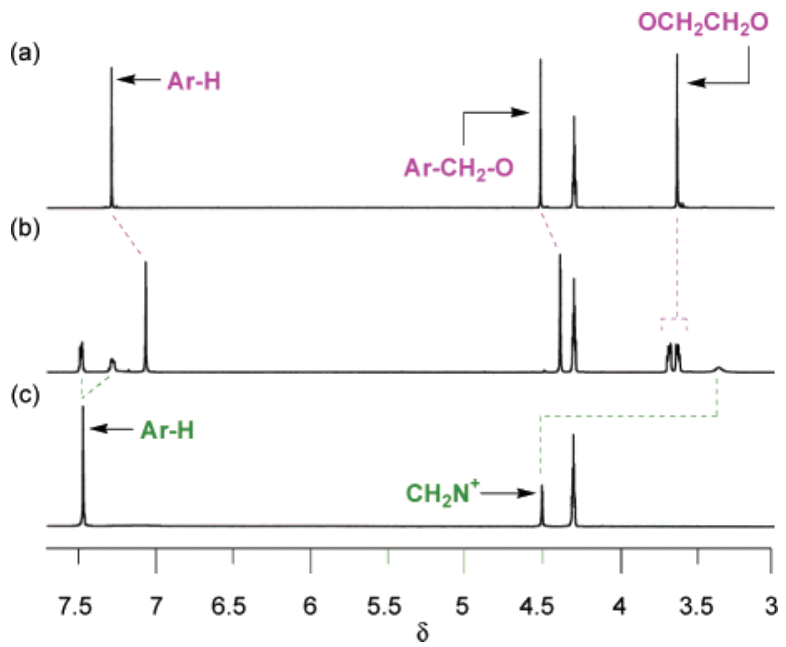

FIGURE 6. Partial ${ }^{1} \mathrm{H}$ NMR spectra $\left(400 \mathrm{MHz}, \mathrm{CD}_{3} \mathrm{NO}_{2}, 298 \mathrm{~K}\right)$ of (a) macrocycle 5, (b) an equimolar mixture of $\mathbf{5}$ and $\mathrm{DBA}^{2} \mathrm{PF}_{6}(20$ $\mathrm{mM}$ ), and (c) $\mathrm{DBA} \cdot \mathrm{PF}_{6}$. beneficial for the binding of a $\mathrm{DBA}^{+}$ion than is a diethylene glycol chain, possibly because of the macrocyclic effect due to (a) its structural rigidity, which places the two phenolic aromatic rings in a better position to take part in the noncovalent interactions between the $\mathrm{CH}_{2} \mathrm{NH}_{2}{ }^{+} \mathrm{CH}_{2}$ center of the threaded $\mathrm{DBA}^{+}$ion, (b) the more-electron-rich aromatic rings, which favor these noncovalent interactions (i.e., a phenolic ring for 1a vs a xylyl group for 5), and (c) the slightly smaller size of the macrocycle (25 ring atoms for 1a, 26 for 5).

Rotaxanes Formed From “Oxygen-Deficient” Macrocycles and $\mathrm{DBA}^{+}$Ions: Synthesis and Thermal Stability. To prove unambiguously that [2]pseudorotaxane complexes form in solution between macrocycles $\mathbf{1 a}$ and $\mathbf{1 b}$ and $\mathrm{DBA}^{+}$ions, we chose to stopper such complexes to form their corresponding [2]rotaxanes. From a CPK molecular model, it appeared that because compound 1a is a 25 -membered-ring macrocycle that incorporates three rigid benzene rings, diethyl phosphoramidate groups $^{33}$ would serve as suitable stoppers. Thus, we added triethyl phosphite $(200 \mathrm{mM})$ to a solution of benzylic azide 6- $\mathrm{H} \cdot \mathrm{PF}_{6}(100 \mathrm{mM})$ and macrocycle $1 \mathbf{a}(150 \mathrm{mM})$ in $\mathrm{CH}_{2} \mathrm{Cl}_{2}$

(30) Chemical double-mutant cycles have been used to measure the strengths of aromatic stacking interactions; the estimated stabilization energies are less than $0.34 \mathrm{kcal} / \mathrm{mol}$, depending on the interacting aromatic system. See: (a) Carver, F. J.; Hunter, C. A.; Jones, P. S.; Livingstone, D. J.; McCabe, J. F.; Seward, E. M.; Tiger, P.; Spey, S. E. Chem. Eur. J. 2001, 7, 4854-4862. (b) Adams, H.; Hunter, C. A.; Lawson, K. R.; Perkins, J.; Spey, S. E.; Urch, C. J.; Sanderson, J. M. Chem. Eur. J. 2001, 7, 48634878 . 


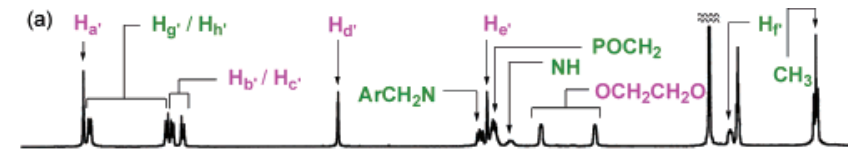

(b)

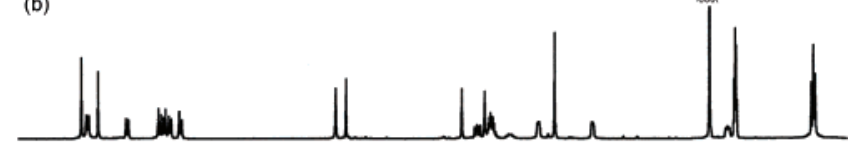

(c)

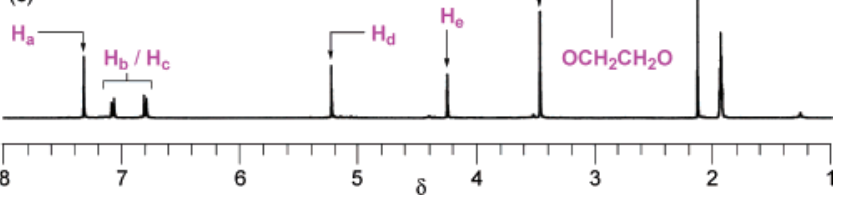

FIGURE 7. Partial ${ }^{1} \mathrm{H}$ NMR spectra (400 MHz, $\mathrm{CD}_{3} \mathrm{CN}, 10 \mathrm{mM}, 298$ $\mathrm{K}$ ) of (a) [2] rotaxane $7-\mathrm{H} \cdot \mathrm{PF}_{6}$, (b) an equimolar mixture of rotaxane 7-H·PF 6 and macrocycle $\mathbf{1 a}$, and (c) macrocycle $\mathbf{1 a}$.

and isolated the corresponding [2] rotaxane $7-\mathrm{H} \cdot \mathrm{PF}_{6}$ in $57 \%$ yield after column chromatography over silica gel. The reaction between macrocycle $\mathbf{1 b}$, benzylic azide $\mathbf{6}-\mathrm{H} \cdot \mathrm{PF}_{6},{ }^{33}$ and triethyl phosphite, however, gave no corresponding [2]rotaxane, probably because macrocycle $\mathbf{1 b}$ contains a 28 -membered ring, which it too large to be entrapped by the diethyl phosphoramidate stoppering units. After inspecting CPK molecular models, we believed that the sterically more sizable dibutyl phosphoramidate groups would be more reasonable choices as stoppers. Gratifyingly, when we added tributyl phosphate $(200 \mathrm{mM})$ to an equimolar mixture of the benzyl azide $6-\mathrm{H} \cdot \mathrm{PF}_{6}$ and macrocycle $\mathbf{1 b}$ in $\mathrm{CH}_{2} \mathrm{Cl}_{2}(100 \mathrm{mM})$ we isolated the corresponding [2]rotaxane $8-\mathrm{H} \cdot \mathrm{PF}_{6}$ in $14 \%$ yield. ${ }^{34}$ The ${ }^{1} \mathrm{H}$ NMR spectrum (Figure 7a) of the [2] rotaxane $7-\mathrm{H} \cdot \mathrm{PF}_{6}$ recorded in $\mathrm{CD}_{3} \mathrm{CN}$ displays upfield shifts in the positions of the signals of the resonances of (a) the methylene protons adjacent to the ammonium center (cf. the corresponding signal for $6-\mathrm{H} \cdot \mathrm{PF}_{6}$ ) and (b) the ethylene protons of the encircled macrocyclic component of $7-\mathrm{H} \cdot \mathrm{PF}_{6}$, relative to the positions of these signals in their free components; these shifts confirm that the interactions between these components in the rotaxane are similar to those present in the initial $[\mathbf{1 a} \supset \mathrm{DBA}]^{+}$complex. The ${ }^{1} \mathrm{H} \mathrm{NMR}$ spectrum (Figure $7 \mathrm{~b}$ ) of an equimolar mixture of $7-\mathrm{H} \cdot \mathrm{PF}_{6}$ and macrocycle 1a (10 mM each) in $\mathrm{CD}_{3} \mathrm{CN}$ at $298 \mathrm{~K}$ corresponds to a superimposition of the two spectra (cf. Figure 7a,c) of the separate components. These spectra establish that no exchange occurs between the macrocycle and dumbbell components in solution and, therefore, proves the constitutional integrity of the [2] rotaxane. ${ }^{35}$ We used a similar method to prove the consti-

(31) (a) Ashton, P. R.; Chrystal, E. J. T.; Glink, P. T.; Menzer, S.; Schiavo, C.; Spencer, N.; Stoddart, J. F.; Tasker, P. A.; White, A. J. P.; Williams, D. J. Chem. Eur. J. 1996, 2, 709-728. (b) Ashton, P. R.; Fyfe, M. C. T.; Hickingbottom, S. K.; Stoddart, J. F.; White, A. J. P.; Williams D. J. J. Chem. Soc., Perkin Trans. 2 1998, 2117-2124.

(32) The association constant $\left(K_{\mathrm{a}}\right)$ between DB24C8 and $\mathrm{DBA}^{+}$ion in $\mathrm{CD}_{3} \mathrm{NO}_{2}$ has been reported to be $8000 \mathrm{M}^{-1}$; see: Chiu, S.-H.; Liao, K.-S.; Su, J.-K. Tetrahedron Lett. 2004, 45, 213-216.

(33) Hung, W.-C.; Liao, K.-S.; Liu, Y.-H.; Peng, S.-M.; Chiu, S.-H. Org. Lett. 2004, 6, 4183-4186.

(34) The lower yield of this reaction may be the result of the lower association constant of the interaction between the $\mathrm{DBA}^{+}$ion and macrocycle $\mathbf{1 b}$, relative to that of macrocycle 1a. Shielding of the ammonium center by the macrocycle has been suggested as an important factor in the success of these stoppering reactions; see ref 33 .

(35) A similar method had been applied previously to prove the structural integrity of rotaxanes; see: Chiu, S.-H.; Stoddart, J. F. J. Am. Chem. Soc. 2002, 124, 4174-4175.

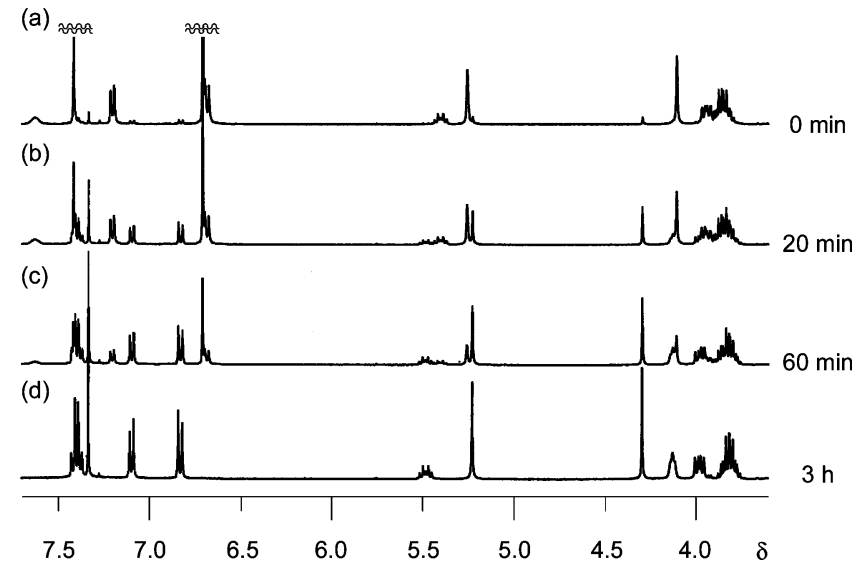

FIGURE 8. Partial ${ }^{1} \mathrm{H}$ NMR $(400 \mathrm{MHz}, 323 \mathrm{~K})$ spectra displaying the dissociation of [2] rotaxane 8- $\mathrm{H} \cdot \mathrm{PF}_{6}$ in $\mathrm{CD}_{3} \mathrm{SOCD}_{3}$ over time: (a) $0 \mathrm{~min}$, (b) $20 \mathrm{~min}$, (c) $60 \mathrm{~min}$, and (d) $3 \mathrm{~h}$.

tutional integrity of [2] rotaxane $\mathbf{8}-\mathrm{H} \cdot \mathrm{PF}_{6}$ (see the Supporting Information).

To test the thermal stability of the phosphoramidate-stoppered [2] rotaxanes $\mathbf{7}-\mathrm{H} \cdot \mathrm{PF}_{6}$ and $\mathbf{8}-\mathrm{H} \cdot \mathrm{PF}_{6}$, we dissolved them individually in $\mathrm{CD}_{3} \mathrm{SOCD}_{3}(5 \mathrm{mM})$ and heated them to $323 \mathrm{~K}$ while monitoring their ${ }^{1} \mathrm{H}$ NMR spectra. The ${ }^{1} \mathrm{H}$ NMR spectrum of [2] rotaxane $\mathbf{7}-\mathrm{H} \cdot \mathrm{PF}_{6}$, in which macrocycle $\mathbf{1 a}$ is entrapped by diethyl phosphoramidate stoppers, was unchanged after heating for $2 \mathrm{~h}$ under these conditions. In contrast, the ${ }^{1} \mathrm{H}$ NMR spectra of the [2] rotaxane $\mathbf{8}-\mathrm{H} \cdot \mathrm{PF}_{6}$ (Figure 8) indicate that the intensity of the signals of the free macrocycle $\mathbf{1 b}$ increased, and those for $\mathbf{8}-\mathrm{H} \cdot \mathrm{PF}_{6}$ decreased; i.e., dissociation of the macrocyclic unit of $8-\mathrm{H} \cdot \mathrm{PF}_{6}$ occurred in $\mathrm{CD}_{3} \mathrm{SOCD}_{3}$ at $323 \mathrm{~K}$. Thus, the di- $n$ butyl phosphoramidate terminus/macrocycle $\mathbf{1 b}$ pair does not constitute a true interlocking system, but rather one that is a slippage-amenable rotaxane system. This result led us to prepare the [2] rotaxane $\mathbf{9}-\mathrm{H} \cdot \mathrm{PF}_{6}$, in which macrocycle $\mathbf{1 b}$ is confined between two slightly larger di- $n$-hexyl phosphoramidate stoppers; this rotaxane is stable as a supramolecular entity in $\mathrm{CD}_{3} \mathrm{SOCD}_{3}$ at $323 \mathrm{~K}$ for at least $2 \mathrm{~h}$.

The fact that it is possible to generate [2]pseudorotaxane complexes in solution from the interaction of $\mathrm{DBA}^{+}$ions with macrocycles $\mathbf{1 a}$ and $\mathbf{1 b}$ that contain loops of just three or four oxygen atoms suggests that the cooperative effect of at least five oxygen atoms found in the recognition sites of most of the crown ethers that have been used previously to complex $\mathrm{DBA}^{+}$ ions is not a necessary prerequisite for efficient binding. Indeed, it appears that $[$ cation $\cdots \pi],\left[\mathrm{N}^{+}-\mathrm{H} \cdots \pi\right]$, and $\left[\mathrm{N}^{+} \mathrm{C}-\mathrm{H} \cdots \pi\right]$ interactions can be harnessed to play extremely important roles in stabilizing macrocycle/dialkylammonium ion complexes.

Macrocycles 1a and 1b Recognize Bipyridinium Ions. Because the two electron-rich phenol rings linked by an ethylene glycol chain are placed in a distance (ca. 7.0 ̊) suitable for $\pi$-stacking-based on CPK molecular models and molecular mechanics calculations - we suspected that macrocycles 1a and 1b may be able to recognize electron-deficient bipyridinium ions in addition to dialkylammonium ions. ${ }^{36}$ When we mixed equimolar amounts $(10 \mathrm{mM})$ of $\mathbf{1 b}$ and methyl viologen bis(hexafluorophosphate) $\mathbf{1 0} \cdot 2 \mathrm{PF}_{6}$ in $\mathrm{CD}_{3} \mathrm{NO}_{2}$, the solution turned yellow immediately. The observation of upfield shifts for the signals of aromatic protons of both $\mathbf{1 b}$ and $\mathbf{1 0} \cdot 2 \mathrm{PF}_{6}$ in ${ }^{1} \mathrm{H} \mathrm{NMR}$ spectra, relative to those of the free species, implies that the $\pi$-electron-deficient bipyridinium ion may be positioned within the cavity of $\mathbf{1 b}$ such that it stacks with the $\pi$-electron-rich 


\section{SCHEME 5}

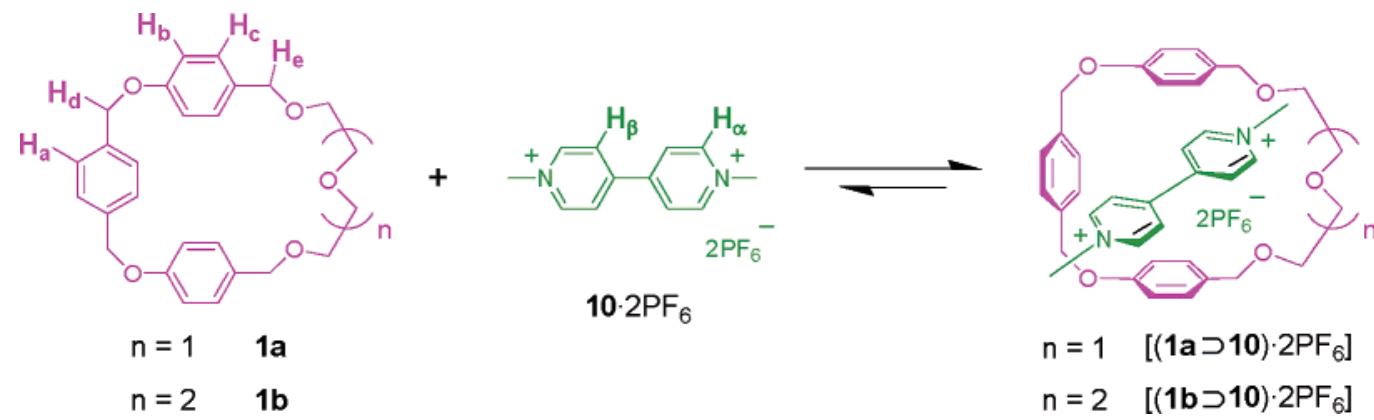

\section{SCHEME 6}

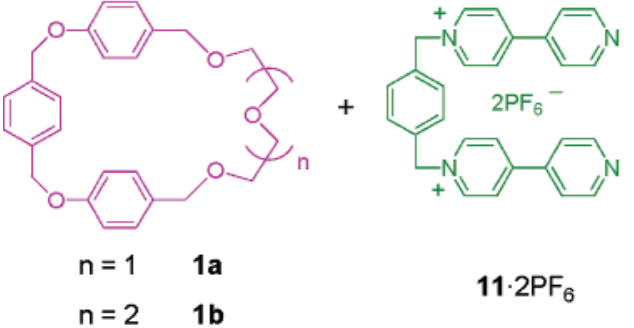

phenol rings to form a [2]pseudorotaxane-like complex. The dispersion of the "tight" multiplet $(\delta 3.48-3.57)$ for the protons of the $\mathrm{OCH}_{2} \mathrm{CH}_{2} \mathrm{O}$ units of uncomplexed $\mathbf{1 b}$ into three distinct signals and the upfield shift of the $\alpha$-protons on the bipyridinium ion (Figure 9) suggest that weak $[\mathrm{C}-\mathrm{H} \cdots \mathrm{O}]$ hydrogen bonds may exist along with $\pi$-stacking interactions in this [2]pseudorotaxane-like complex $\left[(\mathbf{1 b} \supset \mathbf{1 0}) \cdot 2 \mathrm{PF}_{6}\right]$ (cf. the similar shifts observed in the NMR spectra of the complex formed between BPP34C10 and $\mathbf{1 0} \cdot 2 \mathrm{PF}_{6}$ ). ${ }^{36 a, 37}$ From a ${ }^{1} \mathrm{H}$ NMR spectroscopic dilution experiment, we determined the association constant $\left(K_{\mathrm{a}}\right)$ for the complexation between $\mathbf{1 b}$ and $\mathbf{1 0} \cdot 2 \mathrm{PF}_{6}$ in $\mathrm{CD}_{3} \mathrm{NO}_{2}$ to be $130 \pm 3 \mathrm{M}^{-1}$.

We observed similar shifts in the signals of an equimolar mixture of the smaller macrocycle $\mathbf{1 a}$ and $\mathbf{1 0} \cdot 2 \mathrm{PF}_{6}$ under the same conditions (Figure 10); the association constant in this
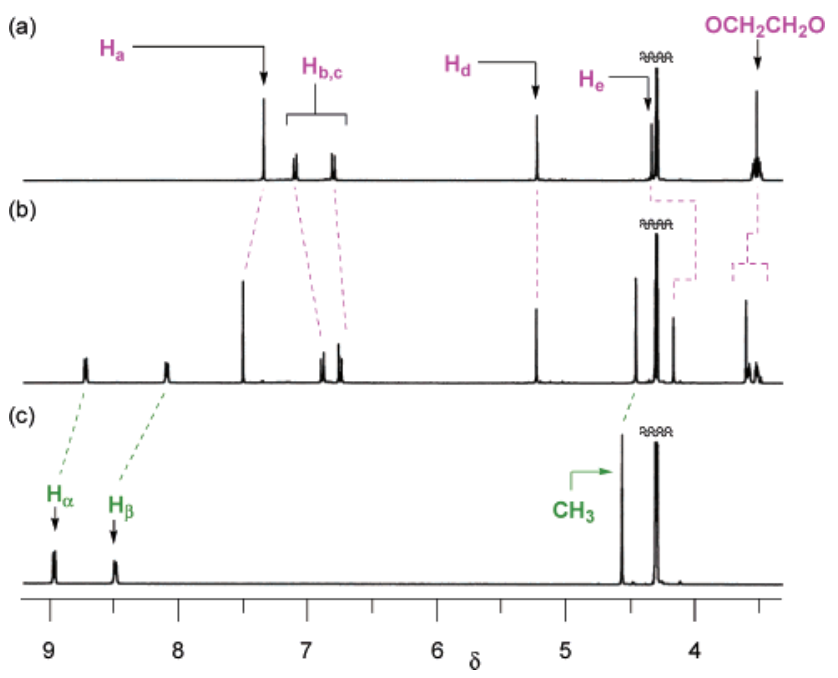

FIGURE 9. Partial ${ }^{1} \mathrm{H}$ NMR spectra $\left(400 \mathrm{MHz}, \mathrm{CD}_{3} \mathrm{NO}_{2}, 298 \mathrm{~K}\right)$ of (a) macrocycle $\mathbf{1 b}$, (b) an equimolar mixture of $\mathbf{1 b}$ and $\mathbf{1 0} \cdot 2 \mathrm{PF}_{6}(10$ $\mathrm{mM}$ ), and (c) $\mathbf{1 0} \cdot 2 \mathrm{PF}_{6}$.

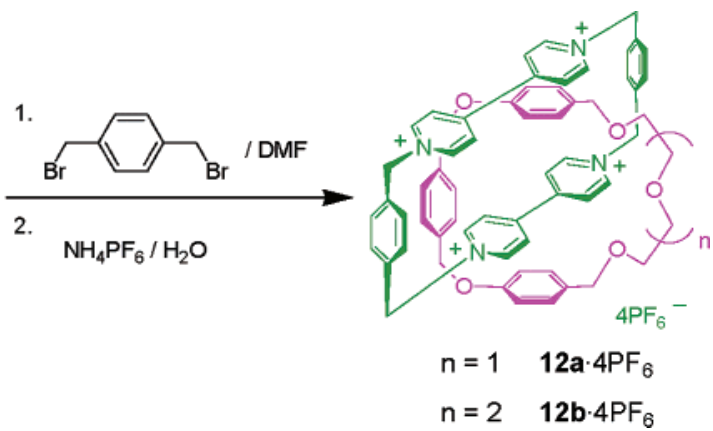

case is $60 \pm 7 \mathrm{M}^{-1}$, i.e., about half that of the interaction between $\mathbf{1 b}$ and $\mathbf{1 0} \cdot 2 \mathrm{PF}_{6}$. This finding implies that even through $\mathbf{1 b}$ is less preorganized for the binding of $\mathrm{DBA}^{+}$ions than is 1a, the extra hydrogen-bond-accepting oxygen atom of its oligoethylene glycol loop and its increased cavity size may be more accommodating for bipyridinium ions such that it may provide simultaneous $\pi$-stacking and $[\mathrm{C}-\mathrm{H} \cdots \mathrm{O}]$ hydrogen bonding interactions.

To prove that the complexes that form between $\mathbf{1 0} \cdot 2 \mathrm{PF}_{6}$ and macrocycles 1a and $\mathbf{1 b}$ have [2]pseudorotaxane-like architectures in solution, we synthesized the corresponding interlocked molecules. We isolated the [2]catenane $\mathbf{1 2 b} \cdot 4 \mathrm{PF}_{6}$ (Scheme 6) comprising the macrocycles $\mathbf{1 b}$ and cyclobis(paraquat- $p$-phenylene) $\left(\mathrm{CBPQT}^{4+}\right)$ as a yellow solid in $29 \%$ yield after reacting 1b, 11.2PF $6{ }^{37}$ and $\alpha, \alpha^{\prime}$-dibromo- $p$-xylene in DMF at ambient temperature. Reacting macrocycle $1 \mathbf{a}$ under the same conditions gave the corresponding [2] catenane $\mathbf{1 2 a} \cdot 4 \mathrm{PF}_{6}$ in $21 \%$ yield. Because these syntheses must proceed via pseudorotaxane-like

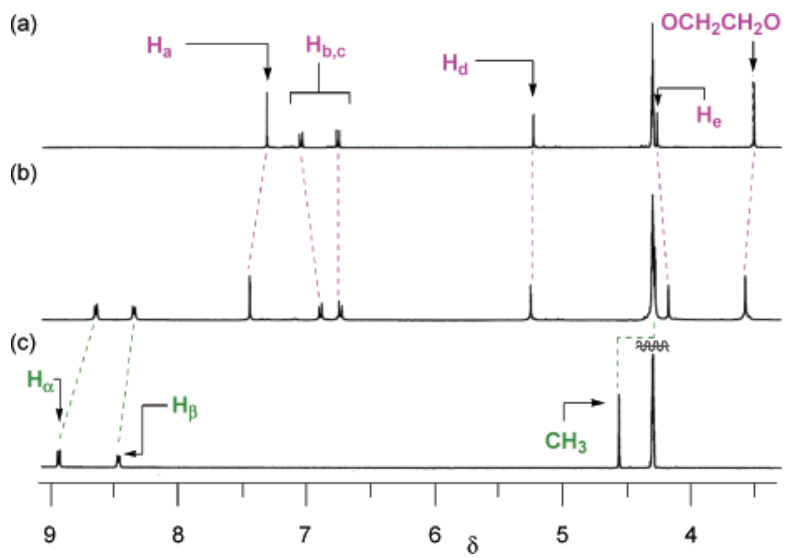

FIGURE 10. Partial ${ }^{1} \mathrm{H}$ NMR spectra $\left(400 \mathrm{MHz}, \mathrm{CD}_{3} \mathrm{NO}_{2}, 298 \mathrm{~K}\right)$ of (a) macrocycle $\mathbf{1 a},\left(\right.$ b) an equimolar mixture of $\mathbf{1 a}$ and $\mathbf{1 0} \cdot 2 \mathrm{PF}_{6}(10$ $\mathrm{mM}$ ), and (c) $10 \cdot 2 \mathrm{PF}_{6}$. 


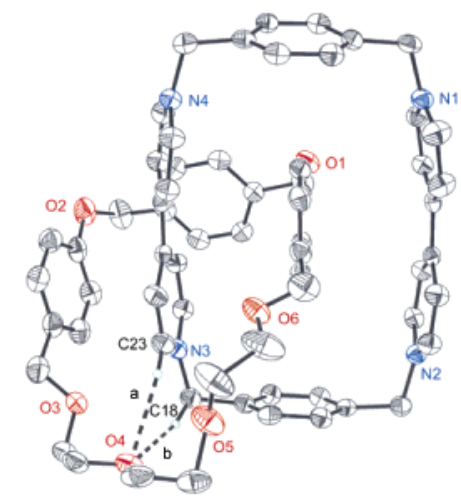

FIGURE 11. Solid-state structure of the $[2]$ catenane $\mathbf{1 2}^{\mathbf{4}}$. Disorder of atoms is observed in the ethylene glycol chain (from $\mathrm{O} 3$ to O6). Hydrogen bond geometries $(\mathrm{C} \cdots \mathrm{O}$ and $\mathrm{H} \cdots \mathrm{O}$ distances $[\AA]$ and $\mathrm{C}-\mathrm{H} \cdots \mathrm{O}$ angles $[\mathrm{deg}]$ ): (a) 3.321(7), 2.45, 153.0; (b) 3.501(7), 2.59, 153.8 .

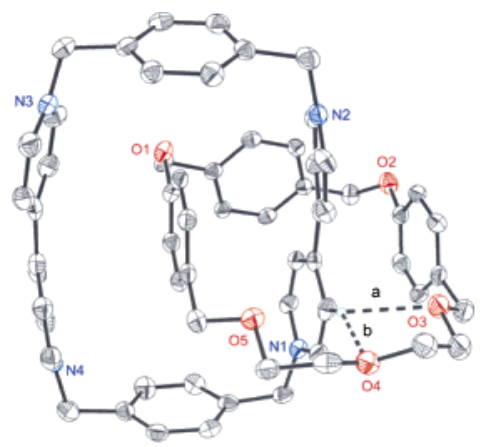

FIGURE 12. Solid-state structure of the $[2]$ catenane $\mathbf{1 2}^{\mathbf{4}+}$. Hydrogen bond geometries $(\mathrm{C} \cdots \mathrm{O}$ and $\mathrm{H} \cdots \mathrm{O}$ distances $[\AA]$ and $\mathrm{C}-\mathrm{H} \cdots \mathrm{O}$ angles [deg]): (a) 2.883(18), 2.39, 112.1; (b) 3.021(18), 2.16, 150.7 .

intermediates, we believe that the successful isolation of these two [2]catenanes proves that macrocycles $\mathbf{1 a}$ and $\mathbf{1 b}$ each bind bipyridinium ions in the form of [2]pseudorotaxane complexes.

We used vapor diffusion of isopropyl ether into respective $\mathrm{CH}_{3} \mathrm{CN}$ solutions of $\mathbf{1 2} \mathbf{a} \cdot 4 \mathrm{PF}_{6}$ and $\mathbf{1 2} \mathbf{b} \cdot 4 \mathrm{PF}_{6}$ to obtain single crystals, which were suitable for X-ray crystallographic analysis, of both of these [2]catenanes. The solid-state structures (Figures 11 and 12) of these two catenanes reveal the expected $\pi$-stacking interactions and $[\mathrm{C}-\mathrm{H} \cdots \mathrm{O}]$ hydrogen bonds between their interlocked macrocycles.

The fact that macrocycles $\mathbf{1 a}$ and $\mathbf{1 b}$ form pseudorotaxanelike complexes with both $\mathrm{DBA}^{+}$and bipyridinium ions in solution makes them suitable candidates for the construction

(36) Bipyridinium ions form pseudorotaxane-like complexes with several sizable crown ethers; see: (a) Allwood, B. L.; Spencer, N.; ShahriariZavareh, H.; Stoddart, J. F.; Williams, D. J. J. Chem. Soc., Chem. Commun. 1987, 1064-1066. (b) Allwood, B. L.; Shahriari-Zavareh, H.; Stoddart, J. F.; Williams, D. J. J. Chem. Soc., Chem. Commun. 1987, 1058-1061. (c) Asakawa, M.; Ashton, P. R.; Ballardini, R.; Balzani, V.; Belohradsky, M.; Gandolfi, M. T.; Kocian, O.; Prodi, L.; Raymo, F. M.; Stoddart, J. F.; Venturi M. J. Am. Chem. Soc. 1997, 119, 302-310. (d) Yamaguchi, N.; Nagvekar, D. S.; Gibson, H. W. Angew. Chem., Int. Ed. Engl. 1998, 37, 2361-2364. (e) Bryant, W. S.; Jones, J. W.; Mason, P. E.; Guzei, I.; Rheingold, A. L.; Fronczek, F. R.; Nagvekar, D. S.; Gibson, H. W. Org. Lett. 1999, 1, 10011004. (f) Huang, F.; Zakharov, L. N.; Rheingold, A. L.; Ashraf-Khorassani, M.; Gibson, H. W. J. Org. Chem. 2005, 70, 809-813.

(37) Anelli, P. L.; Ashton, P. R.; Ballardini, R.; Balzani, V.; Delgado, M.; Gandolfi, M. T.; Goodnow, T. T.; Kaifer, A. E.; Philp, D.; Pietraszkiewicz, M.; Prodi, L.; Reddington, M. V.; Slawin, A. M. Z.; Spencer, N.; Stoddart, J. F.; Vicent, C.; Williams, D. J. J. Am. Chem. Soc. 1992, 114, 193-218. of molecular switches. Although large crown ethers, such as BPP34C10 and BMP32C10, can also recognize both of these guests in solution, small crown ethers, such as DB24C8 and BMP26C8, seem to lack this ability. ${ }^{38}$ To the best of our knowledge, macrocycle 1a is the smallest macrocycle (a 25membered ring) that is capable of complexing both guests in a [2]pseudorotaxane-like fashion in solution. The much smaller ring size of macrocycles $\mathbf{1 a}$ and $\mathbf{1 b}$, when compared to that of BPP34C10, may make the syntheses of their corresponding functional interlocked molecules much easier because they do not require relatively enormous groups, ${ }^{36 c, 39}$ such as tris(4-tertbutylphenyl)methyl units, to serve as effective stopper moieties.

\section{Conclusions}

We have synthesized a new category of macrocycles, containing suitably positioned oligoethylene glycol chains and aromatic rings, that form [2]pseudorotaxane-like complexes with both dialkylammonium and bipyridinium ions in solution. The chemical structures of crown ethers that have been reported to bind $\mathrm{DBA}^{+}$ions have generally comprised oligoethylene glycol chains that provide a cooperative effect of at least five oxygen atoms; in this paper, however, we demonstrate that such a prerequisite is not a necessary one for efficient binding. With suitable design, the cooperative effects of $\left[\mathrm{N}^{+} \mathrm{C}-\mathrm{H} \cdots \pi\right],\left[\mathrm{N}^{+}-\right.$ $\mathrm{H} \cdots \pi$, and [cation $\cdots \pi$ ] interactions in conjunction with moretraditional hydrogen bonds between the macrocycles and $\mathrm{DBA}^{+}$ ions can result in extremely stable pseudorotaxane complexes. That is to say, the oxygen atoms of crown ethers can be replaced by phenol units and still retain their effective binding properties toward $\mathrm{DBA}^{+}$ions. We are currently trying to identify the major noncovalent interactions that occur between macrocycle $\mathbf{1 a}$ and the $\mathrm{DBA}^{+}$ion and stabilize this pseudorotaxane complex. Hopefully, these studies will lead us to a greater understanding and control over less-traditional noncovalent interactions.

\section{Experimental Section}

Computational Details. Stochastic molecular dynamics simulations were performed with MacroModel V9.0 in conjunction with the all-atom AMBER* force-field. ${ }^{40,41}$ The continuum GB/SA model in MacroModel was used for simulations in water. ${ }^{42}$ Constant dielectric treatment was used to estimate the electrostatic interactions. A 200-ps equilibration step with a 1-fs time step was followed

(38) The interaction between $N, N$-dibenzylbipyridinium bis(hexafluorophosphate) and DB24C8 is negligible; see: (a) Martínez-Díaz, M.-V.; Spencer, N.; Stoddart, J. F. Angew. Chem., Int. Ed. Engl. 1997, 36, 19041907. (b) Ashton, P. R.; Langford, S. J.; Spencer, N.; Stoddart, J. F.; White, A. J. P.; Williams, D. J. Chem. Commun. 1996, 1387-1388. The interaction between the $\mathrm{DBA}^{+}$ion and BMP26C8 is also negligible; see refs 13 and 16. When applying the concept of multivalency, however, DB24C8 can interact quite strongly with bipyridinium ions in solution; see: Badjix, J. D.; Cantrill, S. J.; Stoddart, J. F. J. Am. Chem. Soc. 2004, 126, 22882289.

(39) (a) Ashton, P. R.; Philp, D.; Spencer, N.; Stoddart, J. F. J. Chem. Soc., Chem Commun. 1992, 1124-1128. (b) Vignon, S. A.; Jarrosson, T.; Iijima, T.; Tseng, H.-R.; Sanders, J. K. M.; Stoddart, J. F. J. Am. Chem. Soc. 2004, 126, 9884-9885. BPP34C10-based rotaxanes are generally synthesized using slippage approaches. See: (c) Belohradsky, M.; Elizarov, A. M.; Stoddart, J. F. Collect. Czech. Chem. Commun. 2002, 67, 17191728.

(40) Mohamandi, F.; Richards, N. G. J.; Guida, W. C.; Liskamp, R.; Liption, M.; Caufield, C.; Chang, G.; Hendrickson, T.; Still, W. C. J. Comput. Chem. 1990, 11, 400-467.

(41) (a) Weiner, S. J.; Kollman, P. A.; Case, D. A.; Singh, U. C.; Chio, C.; Alagona, G.; Profeta, S.; Weiner, P. J. Am. Chem. Soc. 1984, 106, 765784. (b) Weiner, S. J.; Kollman, P. A.; Case, D. A. J. Comput. Chem. 1986 7, 230-252. 
by a $5000-p s$ MD run with a 1 -fs time step at $300 \mathrm{~K}$. Structures were sampled at regular intervals of 1 ps during the simulations. The sampled structures were then minimized with use of the PR conjugated gradient method to obtain the lowest energy structure in each simulation. A previous study on $\beta$-cyclodextrin complexes has shown this method of locating low-energy structures to be superior to using the Monte Carlo multiple minimum (MCMM) search in MacroModel. ${ }^{43}$ During the MD simulations, the guest changes orientation and position in the host, but no decomplexation was observed. The lowest energy structures of $\mathbf{1 a} \supset \mathrm{DBA}^{+}$and $\mathbf{1 b} \supset \mathrm{DBA}^{+}$are stabilized through a combination of $\left[\mathrm{N}^{+}-\mathrm{H} \cdots \pi\right]$, $\left[\mathrm{N}^{+} \mathrm{C}-\mathrm{H} \cdots \pi\right],\left[\mathrm{N}^{+}-\mathrm{H} \cdots \mathrm{O}\right]$, and $\left[\mathrm{N}^{+} \mathrm{C}-\mathrm{H} \cdots \mathrm{O}\right]$ contacts between the $\mathrm{CH}_{2} \mathrm{NH}_{2}{ }^{+} \mathrm{CH}_{2}$ unit of a threaded $\mathrm{DBA}^{+}$ion and the oxygen atoms and aromatic rings of the macrocycles. Face-to-face and T-shaped $\pi-\pi$ interactions were also observed between the aromatic rings of both the $\mathrm{DBA}^{+}$ion and the macrocycles.

X-ray Diffraction Analyses. The crystals were mounted on a glass fiber. Crystal data were collected on diffractometers installed with monochromatized Mo $\mathrm{K} \alpha$ radiation, $\lambda=0.71073 \AA$ at $T=$ $150 \mathrm{~K}$. All structures were solved by using the SHELXS-9744 and refined with SHELXL-97 $7^{45}$ by full matrix least squares on $F^{2}$ values with restraints of the disordered motifs. Hydrogen atoms were fixed at calculated positions and refined by using a riding mode. For [2] catenane 12a $\cdot 4 \mathrm{PF}_{6}$, the final indices were $R 1=0.0599, w R 2=$ 0.1360 with goodness-of-fit on $F^{2}=0.848$. For [2]catenane $\mathbf{1 2 b} \cdot 4 \mathrm{PF}_{6}$, the final indices were $R 1=0.0669, w R 2=0.1533$ with goodness-of-fit on $F^{2}=0.987$.

[1,4-Phenylenebis(methyleneoxy-4,1-phenylene)]dimethanol (2). A mixture of 4-hydroxybenzyl alcohol (3.72 g, $30 \mathrm{mmol}), \alpha, \alpha^{\prime}$ dibromo- $p$-xylene $(2.63 \mathrm{~g}, 10 \mathrm{mmol})$, and $\mathrm{K}_{2} \mathrm{CO}_{3}(10 \mathrm{~g}, 72.4 \mathrm{mmol})$ in DMF $(50 \mathrm{~mL})$ was heated at $50{ }^{\circ} \mathrm{C}$ for 2 days. The reaction mixture was cooled to room temperature and the organic solvent was evaporated under reduced pressure. The residue was washed with $\mathrm{CH}_{2} \mathrm{Cl}_{2}(500 \mathrm{~mL}), \mathrm{H}_{2} \mathrm{O}(500 \mathrm{~mL})$, and $\mathrm{MeOH}(150 \mathrm{~mL})$ to afford the desired product 2 (3.14 g, 90\%). Mp $196-198{ }^{\circ} \mathrm{C} ;{ }^{1} \mathrm{H}$ NMR (400 MHz, CD $\left.\mathrm{SOCD}_{3}\right) \delta 4.40(\mathrm{~s}, 4 \mathrm{H}), 5.08$ (s, 4H), 6.94 $(\mathrm{d}, J=8 \mathrm{~Hz}, 4 \mathrm{H}), 7.21(\mathrm{~d}, J=8 \mathrm{~Hz}, 4 \mathrm{H}), 7.43(\mathrm{~s}, 4 \mathrm{H}) ;{ }^{13} \mathrm{C} \mathrm{NMR}$ $\left(100 \mathrm{MHz}, \mathrm{CD}_{3} \mathrm{SOCD}_{3}\right) \delta 62.4,68.7,113.9,127.0,127.3,134.1$, 136.0, 156.2; HR-MS (ES) $\mathrm{C}_{22} \mathrm{H}_{22} \mathrm{O}_{4} \mathrm{Na}[\mathrm{M}+\mathrm{Na}]^{+}$calcd $\mathrm{m} / z$ 373.1416, found $m / z$ 373.1450. Anal. Calcd for $\mathrm{C}_{22} \mathrm{H}_{22} \mathrm{O}_{4}$ : C, 75.41; H, 6.33; O, 18.26. Found: C, 75.62; H, 6.27; O, 18.11.

2,9,15,18,21-Pentaoxatetracyclo[21.2.2.2 $\left.2^{4,7} \cdot 2^{10,13}\right]$ hentriaconta1(25),4,6,10,12,23,26,28,30-nonaene (1a). Diethylene glycol ditosylate 3 (5.95 g, $14.4 \mathrm{mmol}$ ) was added slowly to a solution of diol 2 (5.0 g, $14.4 \mathrm{mmol})$ and $\mathrm{NaH}(1.75 \mathrm{~g}, 42.8 \mathrm{mmol})$ in DMF $(700 \mathrm{~mL})$ and the resulting mixture was stirred at room temperature for 7 days. The reaction was quenched by the addition of $\mathrm{MeOH}$ $(10 \mathrm{~mL})$ and then the organic solvent was evaporated under reduced pressure. The residue was partitioned between $\mathrm{H}_{2} \mathrm{O}(500 \mathrm{~mL})$ and $\mathrm{CH}_{2} \mathrm{Cl}_{2}(500 \mathrm{~mL})$; the organic layer was collected, dried $\left(\mathrm{MgSO}_{4}\right)$, and concentrated to afford a crude product, which was then purified by column chromatography $\left(\mathrm{SiO}_{2} ; \mathrm{EtOAc} /\right.$ hexanes, $\left.3: 7\right)$ to give macrocycle 1a as a white solid $(183 \mathrm{mg}, 3 \%)$. Mp $96-98{ }^{\circ} \mathrm{C} ;{ }^{1} \mathrm{H}$ NMR $\left(400 \mathrm{MHz}, \mathrm{CDCl}_{3}\right) \delta 3.48-3.52(\mathrm{~m}, 4 \mathrm{H}), 3.58-3.62(\mathrm{~m}$, $4 \mathrm{H}), 4.39(\mathrm{~s}, 4 \mathrm{H}), 5.17(\mathrm{~s}, 4 \mathrm{H}), 6.65(\mathrm{~d}, J=8 \mathrm{~Hz}, 4 \mathrm{H}), 7.06(\mathrm{~d}, J$ $=8 \mathrm{~Hz}, 4 \mathrm{H}), 7.27(\mathrm{~s}, 4 \mathrm{H}) ;{ }^{13} \mathrm{C} \mathrm{NMR}\left(100 \mathrm{MHz}, \mathrm{CDCl}_{3}\right) \delta 69.1$, 69.6, 70.5, 72.6, 115.6, 127.0, 129.0, 130.3, 136.8, 157.0; HR-MS (ES) $\mathrm{C}_{26} \mathrm{H}_{29} \mathrm{O}_{5}[\mathrm{M}+\mathrm{H}]^{+}$calcd $m / z$ 421.2015, found $m / z$ 421.2008. Anal. Calcd for $\mathrm{C}_{26} \mathrm{H}_{28} \mathrm{O}_{5}$ : C, 74.26; H, 6.71; O, 19.02. Found: C, 74.37; H, 6.78; O, 18.85 .

2,9,15,18,21,24-Hexaoxatetracyclo[24.2.2.2 $\left.2^{4,7} \cdot 2^{10,13}\right]$ tetratriaconta$1(28), 4,6,10,12,26,29,31,33-n o n a e n e ~(1 b)$. Triethylene glycol di-

(42) Still, W. C.; Tempczyk, A.; Hawley, R. C.; Hendrickson, T. J. Am. Chem. Soc. 1990, 112, 6127-6129. 962 .

(44) Sheldrick, G. M. Acta Crystallogr. 1990, A46, 467-473.

(45) Sheldrick, G. M. SHELXL-97, Program for the Refinement of Crystal Structures; University of Gottingen: Gottingen, Germany, 1997. tosylate 4 (2.30 g, $5.0 \mathrm{mmol})$ was added slowly to a solution of diol 2 (1.74 g, $5.0 \mathrm{mmol})$ and $\mathrm{NaH}(368 \mathrm{mg}, 15.0 \mathrm{mmol})$ in DMF $(500 \mathrm{~mL})$; the resulting mixture was stirred at room temperature for 7 days. The reaction was quenched by the addition of $\mathrm{MeOH}$ $(5 \mathrm{~mL})$ and the organic solvent was evaporated under reduced pressure. The residue was partitioned between $\mathrm{H}_{2} \mathrm{O}(300 \mathrm{~mL})$ and $\mathrm{CH}_{2} \mathrm{Cl}_{2}(300 \mathrm{~mL})$; the organic layer was collected, dried $\left(\mathrm{MgSO}_{4}\right)$, and concentrated to afford a crude product, which was then purified by column chromatography $\left(\mathrm{SiO}_{2} ; \mathrm{EtOAc/hexane,} \mathrm{3:7)}\right.$ to give the macrocycle $1 \mathrm{~b}$ as a white solid $(116 \mathrm{mg}, 5 \%)$. Mp $78-79^{\circ} \mathrm{C} ;{ }^{1} \mathrm{H}$ NMR $\left(400 \mathrm{MHz}, \mathrm{CDCl}_{3}\right) \delta 3.50-3.55(\mathrm{~m}, 4 \mathrm{H}), 3.60-3.64(\mathrm{~m}$, $8 \mathrm{H}), 4.40(\mathrm{~s}, 4 \mathrm{H}), 5.19(\mathrm{~s}, 4 \mathrm{H}), 6.75(\mathrm{~d}, J=8 \mathrm{~Hz}, 4 \mathrm{H}), 7.11(\mathrm{~d}, J$ $=8 \mathrm{~Hz}, 4 \mathrm{H}), 7.26(\mathrm{~s}, 4 \mathrm{H}) ;{ }^{13} \mathrm{C}$ NMR $\left(100 \mathrm{MHz}, \mathrm{CDCl}_{3}\right) \delta 69.2$, 69.5, 70.6, 71.0, 72.9, 115.2, 126.6, 129.0, 130.2, 136.8, 157.3; HR-MS (ES) $\mathrm{C}_{28} \mathrm{H}_{33} \mathrm{O}_{6}[\mathrm{M}+\mathrm{H}]^{+}$calcd $\mathrm{m} / \mathrm{z}$ 465.2272, found $\mathrm{m} / \mathrm{z}$ 465.2282. Anal. Calcd for $\mathrm{C}_{28} \mathrm{H}_{32} \mathrm{O}_{6}$ : C, 72.39; $\mathrm{H}, 6.94 ; \mathrm{O}, 20.66$. Found: $\mathrm{C}, 72.23 ; \mathrm{H}, 7.02 ; \mathrm{O}, 20.75$.

Bis-p-xylyl[26]crown-6 (5). $\alpha, \alpha^{\prime}$-Dibromo- $p$-xylene (5.0 g, 19 mmol) was added slowly to a solution of diethylene glycol $(2.0 \mathrm{~g}$, $19 \mathrm{mmol}$ ) and $\mathrm{NaH}(0.98 \mathrm{~g}, 40 \mathrm{mmol})$ in $\mathrm{DMF}(800 \mathrm{~mL})$; the resulting mixture was stirred at room temperature for 7 days. The reaction was quenched by the addition of $\mathrm{MeOH}(10 \mathrm{~mL})$ and the organic solvent was removed under reduced pressure. The residue was partitioned between $\mathrm{H}_{2} \mathrm{O}(500 \mathrm{~mL})$ and $\mathrm{CH}_{2} \mathrm{Cl}_{2}(500 \mathrm{~mL})$; the organic layer was collected, dried $\left(\mathrm{MgSO}_{4}\right)$, and concentrated to afford a crude product, which was then purified by column

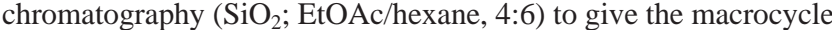
5 as a white solid $(400 \mathrm{mg}, 5 \%)$. Mp $69-70{ }^{\circ} \mathrm{C}$; ${ }^{1} \mathrm{H}$ NMR $(400$ $\left.\mathrm{MHz}, \mathrm{CDCl}_{3}\right) \delta 3.66-3.72(\mathrm{~m}, 16 \mathrm{H}), 4.59(\mathrm{~s}, 8 \mathrm{H}), 7.31(\mathrm{~s}, 8 \mathrm{H})$; ${ }^{13} \mathrm{C}$ NMR $\left(100 \mathrm{MHz}, \mathrm{CDCl}_{3}\right) \delta 69.8,71.2,73.1,127.5,137.5$; HRMS (ES) $\mathrm{C}_{24} \mathrm{H}_{33} \mathrm{O}_{6}[\mathrm{M}+\mathrm{H}]^{+}$calcd $\mathrm{m} / \mathrm{z}$ 417.2277, found $\mathrm{m} / \mathrm{z}$ 417.2201. Anal. Calcd for $\mathrm{C}_{24} \mathrm{H}_{32} \mathrm{O}_{6}$ : C, 69.21; H, 7.74; O, 23.05. Found: $\mathrm{C}, 69.01 ; \mathrm{H}, 7.82 ; \mathrm{O}, 23.17$

[2]Rotaxane 7-H・PF $\mathbf{P}$. Triethyl phosphite $(0.05 \mathrm{~mL}, 0.28 \mathrm{mmol})$ was added slowly to a solution of $6-\mathrm{HPF}_{6}(60 \mathrm{mg}, 0.14 \mathrm{mmol})$ and macrocycle $1 \mathrm{a}$ (90 mg, $0.22 \mathrm{mmol})$ in $\mathrm{CH}_{2} \mathrm{Cl}_{2}(1.4 \mathrm{~mL})$. After the mixture had been stirred at ambient temperature for $16 \mathrm{~h}$, the solvent was evaporated under reduced pressure. The residue was purified chromatographically $\left(\mathrm{SiO}_{2}: \mathrm{CH}_{2} \mathrm{Cl}_{2} / \mathrm{MeOH}, 98: 2\right)$ and the desired [2] rotaxane 7- $\mathrm{HPF}_{6}$ was isolated as a white solid $(90 \mathrm{mg}, 57 \%)$. Mp 85-87 ${ }^{\circ} \mathrm{C} ;{ }^{1} \mathrm{H}$ NMR $\left(400 \mathrm{MHz}, \mathrm{CD}_{3} \mathrm{CN}\right) \delta 1.42(\mathrm{t}, J=6.8$ $\mathrm{Hz}, 12 \mathrm{H}), 2.14(\mathrm{t}, J=6.8 \mathrm{~Hz}, 4 \mathrm{H}), 3.26-3.29(\mathrm{~m}, 4 \mathrm{H}), 3.72-$ $3.74(\mathrm{~m}, 4 \mathrm{H}), 3.97-4.00(\mathrm{~m}, 2 \mathrm{H}), 4.09-4.17(\mathrm{~m}, 8 \mathrm{H}), 4.19(\mathrm{~s}$, $4 \mathrm{H}), 4.23-4.27(\mathrm{~m}, 4 \mathrm{H}), 5.44(\mathrm{~s}, 4 \mathrm{H}), 6.76(\mathrm{~d}, J=10.8 \mathrm{~Hz}, 4 \mathrm{H})$, $6.84(\mathrm{~d}, J=7.6 \mathrm{~Hz}, 4 \mathrm{H}), 6.89(\mathrm{~d}, J=10.8 \mathrm{~Hz}, 4 \mathrm{H}), 7.54(\mathrm{~d}, J=$ $7.6 \mathrm{~Hz}, 4 \mathrm{H}), 7.59(\mathrm{~s}, 4 \mathrm{H}) ;{ }^{13} \mathrm{C} \mathrm{NMR}\left(100 \mathrm{MHz}, \mathrm{CH}_{3} \mathrm{CN}\right) \delta 17.8$ $\left(\mathrm{d}, J_{\mathrm{PC}}=6.9 \mathrm{~Hz}\right), 46.3,52.2,63.8\left(J_{\mathrm{PC}}=5.3 \mathrm{~Hz}\right), 69.1,70.8,72.1$, $75.2,117.3,128.7,128.8,129.6,129.7,130.5,132.4,138.6,142.9$ $\left(\mathrm{d}, J_{\mathrm{PC}}=5.3 \mathrm{~Hz}\right), 158.6$; HR-MS $(\mathrm{ES}) \mathrm{C}_{50} \mathrm{H}_{68} \mathrm{~N}_{3} \mathrm{O}_{11} \mathrm{P}_{2}[7-\mathrm{H}]^{+}$calcd $\mathrm{m} / \mathrm{z}$. 948.4329, found $\mathrm{m} / \mathrm{z}, 948.4332$.

[2]Rotaxane 8-H·PF $\mathbf{6}$. Tributyl phosphite $(0.1 \mathrm{~mL}, 0.36 \mathrm{mmol})$ was added slowly to a solution of $\mathbf{6}-\mathrm{H} \cdot \mathrm{PF}_{6}(81 \mathrm{mg}, 0.18 \mathrm{mmol})$ and macrocycle $\mathbf{1 b}(83 \mathrm{mg}, 0.18 \mathrm{mmol})$ in $\mathrm{CH}_{2} \mathrm{Cl}_{2}(1.8 \mathrm{~mL})$. After the mixture had been stirred at ambient temperature for $16 \mathrm{~h}$, the solvent was evaporated under reduced pressure. The residue was purified by chromatography $\left(\mathrm{SiO}_{2}: \mathrm{CH}_{2} \mathrm{Cl}_{2} / \mathrm{MeOH}, 98: 2\right)$ and the desired [2] rotaxane $\mathbf{8}-\mathrm{H} \cdot \mathrm{PF}_{6}$ was isolated as a colorless oil (30 $\mathrm{mg}$, $14 \%) .{ }^{1} \mathrm{H}$ NMR $\left(400 \mathrm{MHz}, \mathrm{CDCl}_{3}\right) \delta 0.90-0.94(\mathrm{t}, J=7.6 \mathrm{~Hz}$, $12 \mathrm{H}), 1.36-1.45(\mathrm{~m}, 8 \mathrm{H}), 1.62-1.69(\mathrm{~m}, 8 \mathrm{H}), 3.08-3.11(\mathrm{~m}, 4 \mathrm{H})$, $3.24(\mathrm{~s}, 4 \mathrm{H}), 3.32-3.35(\mathrm{~m}, 4 \mathrm{H}), 3.51-3.54(\mathrm{~m}, 4 \mathrm{H}), 3.97-4.06$ (m, 10H), 4.14 (d, $J=8 \mathrm{~Hz}, 4 \mathrm{H}), 4.19$ (s, 4H), 5.18 (s, 4H), 6.73 $(\mathrm{d}, J=8 \mathrm{~Hz}, 4 \mathrm{H}), 6.79(\mathrm{~d}, J=8 \mathrm{~Hz}, 4 \mathrm{H}), 6.89(\mathrm{~d}, J=8 \mathrm{~Hz}, 4$ $\mathrm{H}), 7.28-7.35(\mathrm{~m}, 8 \mathrm{H}) ;{ }^{13} \mathrm{C} \mathrm{NMR}\left(100 \mathrm{MHz}, \mathrm{CDCl}_{3}\right) \delta 14.1,19.2$, $32.7\left(\mathrm{~d}, J_{\mathrm{PC}}=7 \mathrm{~Hz}\right), 45.0,51.2,66.5,66.6,68.3,70.4\left(\mathrm{~d}, J_{\mathrm{PC}}=5\right.$ Hz), 74.1, 114.8, 126.8, 127.3, 128.3, 128.5, 128.6, 128.8, 129.6, 136.3, 141.5, 157.2; HR-MS (ES) $\mathrm{C}_{60} \mathrm{H}_{88} \mathrm{~N}_{3} \mathrm{O}_{12} \mathrm{P}_{2}[8-\mathrm{H}]^{+}$calcd $m / z$ 1104.5844, found $\mathrm{m} / \mathrm{z} 1104.5816$.

[2]Rotaxane 9-H·PF . Trihexyl phosphite $(0.08 \mathrm{~mL}, 0.22 \mathrm{mmol})$ was added slowly to a solution of $\mathbf{6}-\mathrm{H} \cdot \mathrm{PF}_{6}(49 \mathrm{mg}, 0.11 \mathrm{mmol})$ 
and macrocycle $\mathbf{1 b}(50 \mathrm{mg}, 0.11 \mathrm{mmol})$ in $\mathrm{CH}_{2} \mathrm{Cl}_{2}(0.7 \mathrm{~mL})$. After the mixture had been stirred at ambient temperature for $16 \mathrm{~h}$, the solvent was evaporated under reduced pressure. The residue was purified by chromatography $\left(\mathrm{SiO}_{2}: \mathrm{CH}_{2} \mathrm{Cl}_{2} / \mathrm{MeOH}, 98: 2\right)$ and the desired [2] rotaxane $9-\mathrm{H} \cdot \mathrm{PF}_{6}$ was isolated as a colorless oil $(37 \mathrm{mg}$, 25\%). ${ }^{1} \mathrm{H}$ NMR (400 MHz, $\left.\mathrm{CDCl}_{3}\right) \delta 0.88(\mathrm{t}, J=8 \mathrm{~Hz}, 12 \mathrm{H})$, $1.25-1.40(\mathrm{~m}, 24 \mathrm{H}), 1.62-1.72(\mathrm{~m}, 8 \mathrm{H}), 3.12(\mathrm{~s}, 4 \mathrm{H}), 3.27(\mathrm{~s}$, $4 \mathrm{H}), 3.36(\mathrm{~s}, 4 \mathrm{H}), 3.54(\mathrm{~s}, 4 \mathrm{H}), 4.00-4.04(\mathrm{~m}, 10 \mathrm{H}), 4.15$, (d, $J=$ $12 \mathrm{~Hz}, 4 \mathrm{H}), 4.20$ (s, 4H), $5.20(\mathrm{~s}, 4 \mathrm{H}), 6.74(\mathrm{~d}, 4 \mathrm{H}), 6.79(\mathrm{~d}, J=$ $8 \mathrm{~Hz}, 4 \mathrm{H}), 6.89(\mathrm{~d}, J=8 \mathrm{~Hz}, 4 \mathrm{H}), 7.31-7.33(\mathrm{~m}, 8 \mathrm{H}) ;{ }^{13} \mathrm{C} \mathrm{NMR}$ $\left(100 \mathrm{MHz}, \mathrm{CDCl}_{3}\right) \delta 14.1,22.6,25.3,29.8,30.4,30.5,31.4(\mathrm{~d}$, $\left.J_{\mathrm{PC}}=3 \mathrm{~Hz}\right), 44.9,51.1,66.7,68.3,70.3,70.5,74.1,115.0,127.6$, $128.5,128.7,129.0,129.8,136.5,141.5,157.5$; HR-MS (ES) $\mathrm{C}_{68} \mathrm{H}_{104} \mathrm{~N}_{3} \mathrm{O}_{12} \mathrm{P}_{2}[9-\mathrm{H}]^{+}$calcd $m / z$ 1216.7095, found $m / z$ 1216.7135.

[2]Catenane $12 \mathbf{a} \cdot 4 \mathbf{P F}_{6} \cdot \alpha, \alpha^{\prime}$-Dibromo- $p$-xylene $(32 \mathrm{mg}, 0.12$ mmol) was added slowly to a solution of $11 \cdot 2 \mathrm{PF}_{6}(85 \mathrm{mg}, 0.12$ $\mathrm{mmol})$ and $1 \mathrm{a}(50 \mathrm{mg}, 0.12 \mathrm{mmol})$ in DMF $(1 \mathrm{~mL})$; the resulting mixture was stirred at ambient temperature for $24 \mathrm{~h}$. The solvent was evaporated under reduced pressure, the residue was dissolved in $\mathrm{MeCN}(10 \mathrm{~mL})$, and then saturated aqueous $\mathrm{NH}_{4} \mathrm{PF}_{6}(20 \mathrm{~mL})$ was added. The organic solvent was evaporated and the precipitate was collected and washed with $\mathrm{H}_{2} \mathrm{O}(5 \mathrm{~mL})$ to afford a yellow solid, which was recrystallized (MeCN/isopropyl ether) to afford the desired [2] catenane $\mathbf{1 2} \mathbf{a} \cdot 4 \mathrm{PF}_{6}$ as a yellow solid $(38 \mathrm{mg}, 21 \%)$. $\mathrm{Mp}>252{ }^{\circ} \mathrm{C} \mathrm{dec} ;{ }^{1} \mathrm{H}$ NMR $\left(400 \mathrm{MHz}, \mathrm{CD}_{3} \mathrm{CN}\right) \delta 3.01(\mathrm{~s}, 2 \mathrm{H})$, $3.27(\mathrm{~d}, J=8 \mathrm{~Hz}, 2 \mathrm{H}), 3.56-3.62(\mathrm{~m}, 6 \mathrm{H}), 3.72-3.74(\mathrm{~m}, 4 \mathrm{H})$, $3.78-3.83(\mathrm{~m}, 2 \mathrm{H}), 5.05(\mathrm{~s}, 2 \mathrm{H}), 5.09-5.11(\mathrm{~m}, 2 \mathrm{H}), 5.32(\mathrm{~s}$, 2H), $5.58(\mathrm{~d}, J=13 \mathrm{~Hz}, 2 \mathrm{H}), 5.70(\mathrm{~d}, J=13 \mathrm{~Hz}, 2 \mathrm{H}), 5.74$ (s, $4 \mathrm{H}), 6.08(\mathrm{~d}, J=8 \mathrm{~Hz}, 2 \mathrm{H}), 6.40(\mathrm{~d}, J=8 \mathrm{~Hz}, 2 \mathrm{H}), 7.74-7.77$ $(\mathrm{m}, 2 \mathrm{H}), 7.83-7.87(\mathrm{~m}, 12 \mathrm{H}), 7.97(\mathrm{~d}, J=8 \mathrm{~Hz}, 2 \mathrm{H}), 8.35(\mathrm{~d}, J$ $=6 \mathrm{~Hz}, 2 \mathrm{H}), 8.48-8.54(\mathrm{~m}, 2 \mathrm{H}), 8.72(\mathrm{~d}, J=8 \mathrm{~Hz}, 2 \mathrm{H}), 8.85(\mathrm{~d}$, $J=8 \mathrm{~Hz}, 4 \mathrm{H}) ;{ }^{13} \mathrm{C}$ NMR $\left(100 \mathrm{MHz}, \mathrm{CD}_{3} \mathrm{CN}\right) \delta 65.0,65.3,67.5$, 67.7, 70.1, 70.7, 71.7, 73.0, 113.6, 115.3, 125.3, 126.7, 128.0, 128.5, 129.9, 130.0, 130.1, 130.8, 131.1, 137.1, 137.6, 138.9, 139.4, 141.7,
$142.2,144.6,144.9,147.0,154.4,156.5$ (one signal is missing, presumably because of signal overlap); HR-MS (ES) $\mathrm{C}_{62} \mathrm{H}_{58} \mathrm{~N}_{4} \mathrm{O}_{5}$ $[12 \mathrm{a}-2 \mathrm{H}]^{2+}$ calcd $\mathrm{m} / \mathrm{z}, 469.2203$, found $\mathrm{m} / \mathrm{z} 469.2198$.

[2]Catenane 12b·4PF 6 • $\alpha, \alpha^{\prime}$-Dibromo- $p$-xylene (26.2 mg, 0.1 $\mathrm{mmol}$ ) was added slowly to a solution of $\mathbf{1 1}(70.6 \mathrm{mg}, 0.1 \mathrm{mmol})$ and $\mathbf{1 b}$ (46.6 mg, $0.1 \mathrm{mmol})$ in DMF (1 mL); the resulting mixture was stirred at ambient temperature for $24 \mathrm{~h}$. The organic solvent was evaporated under reduced pressure, the residue was dissolved in $\mathrm{MeCN}(10 \mathrm{~mL})$, and then saturated aqueous $\mathrm{NH}_{4} \mathrm{PF}_{6}(20 \mathrm{~mL})$ was added. The solvent was evaporated and the precipitate was collected and washed with $\mathrm{H}_{2} \mathrm{O}(5 \mathrm{~mL})$ to afford a yellow solid, which was recrystallized (MeCN/isopropyl ether) to afford the desired [2]catenane 12b·4PF 6 (46 mg, 29\%). $\mathrm{Mp}>228{ }^{\circ} \mathrm{C} \mathrm{dec} ;{ }^{1} \mathrm{H}$ NMR (400 MHz, $\left.\mathrm{CD}_{3} \mathrm{CN}\right) \delta 3.43-3.52(\mathrm{br}, 4 \mathrm{H}), 3.53-3.55(\mathrm{~m}$, $4 \mathrm{H}), 3.67-3.69(\mathrm{~m}, 4 \mathrm{H}), 3.78(\mathrm{~s}, 4 \mathrm{H}), 5.16(\mathrm{~s}, 4 \mathrm{H}), 5.68(\mathrm{~s}, 8 \mathrm{H})$, 7.27 (br, 8H), 7.74 (s, 4H), $7.83(\mathrm{~s}, 8 \mathrm{H}), 8.71$ (br, 8H) [one signal $(8 \mathrm{H})$ is missing, presumably because of severe signal broadening]; ${ }^{13} \mathrm{C}$ NMR $\left(100 \mathrm{MHz}, \mathrm{CD}_{3} \mathrm{CN}\right) \delta 65.1,67.7,70.6,70.7,71.2,71.7$, $114.5,126.6,128.3,129.3,130.8,137.1,138.4,144.2,146.4,155.3$ (one signal is missing, presumably because of signal overlap); HRMS (FAB) $\mathrm{C}_{64} \mathrm{H}_{64} \mathrm{~N}_{4} \mathrm{O}_{6} \mathrm{P}_{3} \mathrm{~F}_{18}\left[\mathbf{1 2 b} \cdot 3 \mathrm{PF}_{6}\right]^{+}$calcd $\mathrm{m} / \mathrm{z}$ 1419.3751, found $\mathrm{m} / \mathrm{z}, 1419.3778$.

Acknowledgment. We thank the anonymous reviewers for their helpful suggestions and the National Science Council, Taiwan (NSC-93-2113-M-002-020), for the financial support.

Supporting Information Available: ${ }^{1} \mathrm{H}$ and ${ }^{13} \mathrm{C}$ NMR spectra for all new compounds and Job plots for the complexation between macrocycles $\mathbf{1 a}, \mathbf{1 b}$, and $\mathbf{5}$ and $\mathrm{DBA} \cdot \mathrm{PF}_{6}$. This material is available free of charge via the Internet at http://pubs.acs.org.

JO052411+ 